\title{
Easy-to-Synthesize Spirocyclic Compounds Possess Remarkable In Vivo Activity Against Mycobacterium Tuberculosis
}

Ana Guardia, ${ }^{\dagger}$ Jessica Baiget, ${ }^{\ddagger}$ Mónica Cacho, ${ }^{\dagger}$ Arancha Pérez, ${ }^{\dagger}$ Montserrat Ortega-Guerra, ${ }^{\dagger}$ Winston Nxumalo, ${ }^{\dagger}$ Setshaba D. Khanye, ${ }^{\dagger}$ Joaquín Rullas,${ }^{\dagger}$ Fátima Ortega,${ }^{\dagger}$ Elena Jiménez, ${ }^{\dagger}$ Esther Pérez-

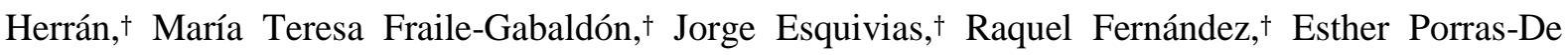
Francisco,${ }^{\dagger}$ Lourdes Encinas, ${ }^{\dagger}$ Marta Alonso, ${ }^{\dagger}$ Ilaria Giordano,${ }^{\dagger}$ Cristina Rivero,${ }^{\dagger}$ Juan Miguel-Siles,$\dagger$ Javier G. Osende, ${ }^{\ddagger}$ Katrina A. Badiola, ${ }^{\ddagger}$ Peter J. Rutledge, ${ }^{\ddagger}$ Matthew H. Todd, ${ }^{*} \ddagger \S$ Modesto Remuiñán, ${ }^{\dagger}$ and Carlos Alemparte*†

†GlaxoSmithKline, Tres Cantos Medicines Development Campus, Severo Ochoa 2, 28760 Tres Cantos, Madrid, Spain

₹School of Chemistry, The University of Sydney, NSW 2006, Australia

§School of Pharmacy, University College London, 29-39 Brunswick Square, London WC1N 1AX, UK

ABSTRACT: Society urgently needs new, effective medicines for the treatment of tuberculosis. To kick-start the required hit-to-lead campaigns, the libraries of pharmaceutical companies have recently been evaluated for starting points. The GlaxoSmithKline (GSK) library yielded many high-quality hits and the associated data were placed in the public domain to stimulate engagement by the wider community. One such series, the Spiro compounds, are described here. The compounds were explored by a combination of traditional in-house research and open source methods. The series benefits from a particularly simple structure and a short associated synthetic chemistry route. Many members of the series displayed striking potency and low toxicity, and highly promising in vivo activity in a mouse model was confirmed with one of the analogs. Ultimately the series was discontinued due to concerns over safety, but the associated data remain public domain, empowering others to resume the series if the perceived deficiencies can be overcome. 


\section{INTRODUCTION}

Tuberculosis (TB) is a major public health problem, with one-third of the world's population infected with the causative agent, Mycobacterium tuberculosis, resulting in 10 million new cases of clinical TB in 2017 and over 4,000 deaths, daily. ${ }^{1}$ The End TB Strategy, adopted by the World Health Assembly in 2014, aims in the next 15 years to reduce TB deaths by $90 \%$ and reduce new cases by $80 \%$. The Strategy's resolutions explicitly call for the development of new drugs, yet few new treatments have been approved in recent decades, ${ }^{2}$ and the pipeline remains weak. ${ }^{3}$ The pressing need for new small molecule therapeutics is made greater by the emergence of multi- and totally-resistant strains, ${ }^{4,5}$ and the troubling finding that resistance can arise without fitness costs. ${ }^{6}$ Even where new therapeutics are developed and are made available, the associated costs of access can severely limit the numbers of people treated, ${ }^{7}$ illustrating the importance of pursuing simple, inexpensive medicines if the burden of $\mathrm{TB}$ is to be genuinely reduced. New initiatives continue to pursue candidate compounds. These range from screening libraries within pharmaceutical companies and sharing the resulting data openly ${ }^{8}$ through to new incentive mechanisms to stimulate research and development. ${ }^{9}$ From a high-throughput screening campaign of GSK's corporate compound collection, the spirocyclic compound 1 was identified as a promising antitubercular hit from a cluster of seven compounds (termed the "Spiro" series) (Table 1). ${ }^{10}$ As previously reported, treatment of Mycobacterium bovis BCG with 1 produced accumulation of intracellular trehalose monomycolate (TMM) by interfering with the ability of MmpL3 to act as a TMM transporter. ${ }^{11}$ MmpL3 protein is a member of the MmpL (Mycobacterial membrane protein Large) family of transporters that has been identified as essential for $M t b$ viability. ${ }^{12}$ MmpL3 has been recently identified as a promising target for TB; in fact, several new TB inhibitors with structural diversity, including the drug candidate SQ109, may interact with MmpL3 as a mode of action ${ }^{13}$ though there remains uncertainty over whether the mechanism of action is via a direct inhibition or a related perturbation in the transmembrane proton gradient. ${ }^{14}$

\section{Table 1. Profile of Initial Hit 1.}




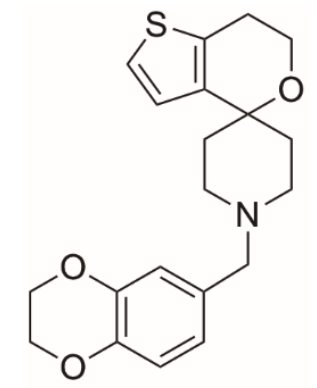

1

\begin{tabular}{|c|c|}
\hline Parameter & 1 \\
\hline Mtb H37Rv MIC90 $(\mu \mathrm{M})$ & 0.30 \\
\hline$M t b \mathrm{MIC}_{90}(\mu \mathrm{M})(108$ strains $)$ & 0.60 \\
\hline Intracellular H37Rv $\mathrm{MIC}_{80}(\mu \mathrm{M})$ & 0.25 \\
\hline Antibacterial panel $\mathrm{IC}_{50}(\mu \mathrm{M})$ & $\geq 16$ \\
\hline Mammalian cell (HepG2) Tox $50(\mu \mathrm{M})$ & 36 \\
\hline $\operatorname{clog} \mathrm{P}$ & 2.99 \\
\hline $\mathrm{CL}_{\text {int }}(\mathrm{mL} / \mathrm{min} \cdot \mathrm{g})$ mouse microsomes & $>30$ \\
\hline $\mathrm{CL}_{\text {int }}(\mathrm{mL} / \mathrm{min} \cdot \mathrm{g})$ human microsomes & 25 \\
\hline Solubility CLND $(\mu \mathrm{M})$ & 266 \\
\hline
\end{tabular}

The compound's intra-macrophage activity, selectivity for mycobacteria $v s$. other bacterial species, and potency against a broad panel of clinical isolates including MDR and XDR strains, in vitro -cidal behavior and a low frequency of spontaneous resistance ${ }^{13 a}$ suggested a highly promising antitubercular profile. The low microsomal stability was a concern and required improvement. In this paper, we report our efforts to optimize this family of compounds through the synthesis of analogs aimed at retaining the antitubercular potency while improving the overall profile for the series.

\section{RESULTS AND DISCUSSION}

\section{Synthesis and In Vitro Evaluation of Analogs}

Aiming to explore the chemical space of the series, a library of novel compounds was synthesized and evaluated. The compounds were isolated either as free amines or as salts (hydrochloride or 
trifluoroacetate, see Experimental Section and Supporting Information), but for simplicity only the parent compound is drawn throughout the paper. The three different regions of the molecule were explored in turn: the northern part (the thiophene ring), the central part (methylenepiperidine moiety) and the southern part (the aryl pendant).

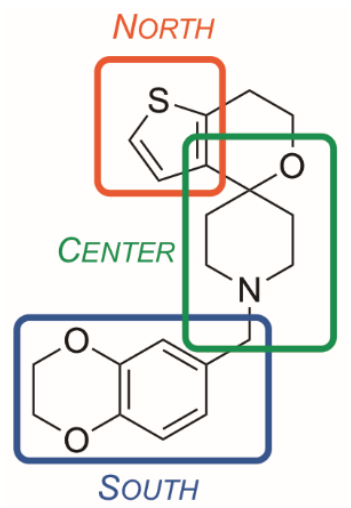

Figure 1. Areas of variation in the synthetic chemistry towards understanding the SAR.

1) Modifications to the North. The first region to be explored for determination of the StructureActivity Relationship (SAR) was the northern part of the molecule, with a view to replacing the thiophene group that had the potential to promote oxidative metabolism. ${ }^{15}$ These analogs were obtained using an oxa-Pictet Spengler reaction on 1-benzyl-4-piperidinone with different aryl alcohols under mild conditions (Scheme 1). ${ }^{16}$ Subsequent $\mathrm{N}$-deprotection and reductive amination with 4benzodioxane-6-carboxaldehyde generated the corresponding compounds that were evaluated (Table 2). The thiophene isomer of 1 (i.e. 4,7-dihydro-5H-thieno[2,3-c]pyran) was found to be inactive, but the sample displayed instability under ambient conditions (visual color degradation, and appearance of new signals in the ${ }^{1} \mathrm{H}$ NMR spectrum) that made its assessment challenging (Compound S1, Supporting Information). Compounds $\mathbf{2}$ and $\mathbf{3}$ were instead found to exhibit superior stability and confirm the strong link between thiophene orientation and biological potency. The benzopyran analogue $\mathbf{4}$ was better tolerated than the indole analogue $\mathbf{6}$, but the addition of a methoxy group on the phenyl ring (5) in order to block potential metabolic reactions resulted in loss of potency.

\section{Scheme 1. Synthesis of Compounds with Modifications to the Northern part}




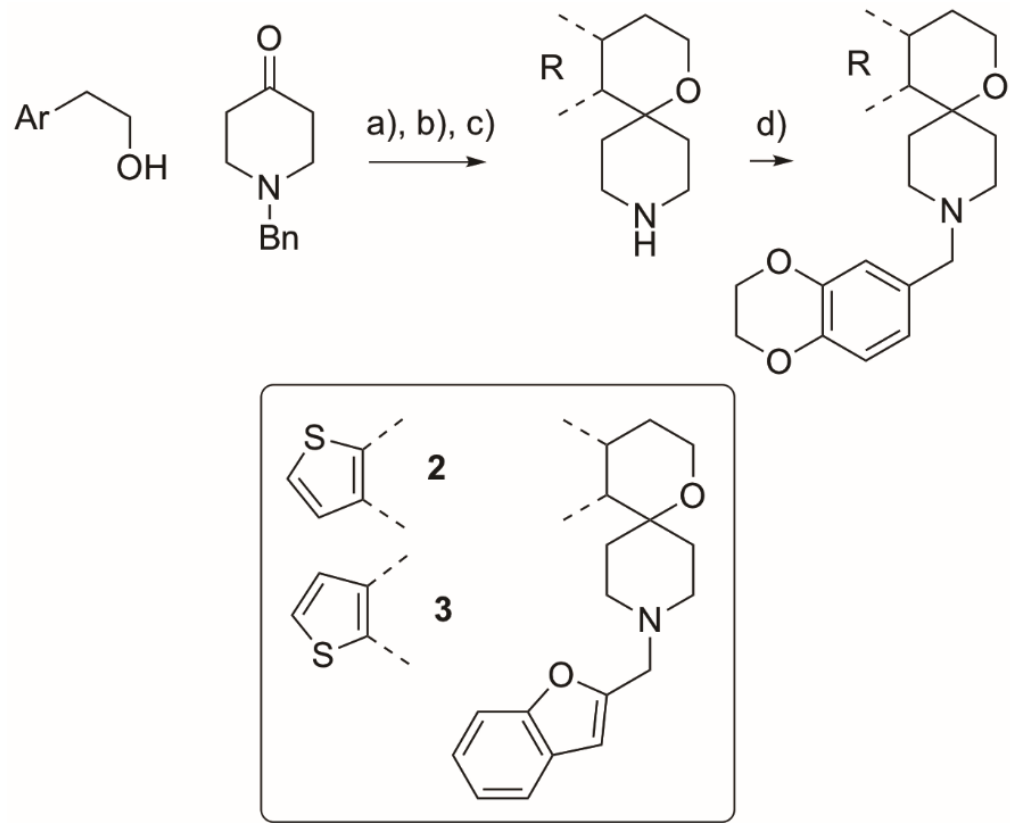

Reagents and Conditions: a) $\mathrm{MsOH}$, toluene, $80^{\circ} \mathrm{C}, 3 \mathrm{~h}$; b) 1-chloroethyl chloroformate, $\mathrm{THF},-78^{\circ} \mathrm{C}, 90 \mathrm{~min}$; c) $\mathrm{MeOH}, 65^{\circ} \mathrm{C}, 1 \mathrm{~h}$; d) 1,4-benzodioxan-6-carboxaldehyde (or benzofuran-2-carbaldehyde for compounds 2 and 3), $\mathrm{NaBH}(\mathrm{OAc})_{3}, \mathrm{DCM}$ or DCE, $40-100^{\circ} \mathrm{C}, 1.5-48 \mathrm{~h}$.

Table 2. Evaluation of Analogs Modified in the Northern Part

\begin{tabular}{|c|c|c|c|c|c|}
\hline Compound & $\mathbf{R}$ & $\begin{array}{l}\text { Mtb H37Rv } \\
\text { MIC90 }(\mu \mathrm{M})\end{array}$ & Compound & $\mathbf{R}$ & $\begin{array}{l}\text { Mtb H37Rv } \\
\text { MIC90 }(\mu \mathrm{M})\end{array}$ \\
\hline 1 & & 0.30 & 4 & & 0.94 \\
\hline 2 & see Scheme 1 & 2.7 & 5 & & $>10$ \\
\hline 3 & see Scheme 1 & $>100$ & 6 & & 93 \\
\hline
\end{tabular}

2) Modifications to the Center. The second region to be examined was the central part of the molecule, in order to verify the importance of the methylenepiperidine moiety (Scheme 2). The amine $7^{16}$ was coupled with the appropriate carboxylic acid, sulfonyl chloride and isocyanate to afford the corresponding amide 8, sulfonamide 9 and urea 10, respectively. The five-membered ring analog (12) and the open-chain compounds (14) were synthesized from 2-(thiophen-2-yl)ethanol with the oxa- 
Pictet Spengler reaction as before, employing the appropriate Cbz-protected ketone or aldehyde as the coupling partner, followed by deprotection and reductive amination with 2,3-dihydro-1,4benzodioxin-6-carbaldehyde. The quaternary analog 15 was synthesized in a two-step sequence from 2-(4-methyl-6,7-dihydro-4H-thieno[3,2-c]pyran-4-yl)ethanol which was subjected to mesylation and nucleophilic substitution with the relevant amine, 2,3-dihydro-1,4-benzodioxin-6-ylmethylamine. Replacement of the methylene group between the piperidine and benzene rings with amide, sulfonamide or urea groups generated inactive molecules (Table 3). Similar results were obtained when the piperidine moiety was replaced with a pyrrolidine moiety. Interestingly, the acyclic analogues, which lack the spirocyclic structure, were also inactive. This set of molecules revealed the importance of the methyl dihydrospiropiperidine structure for retaining antitubercular activity.

\section{Scheme 2. Synthesis of Compounds with Modifications to the Central part}

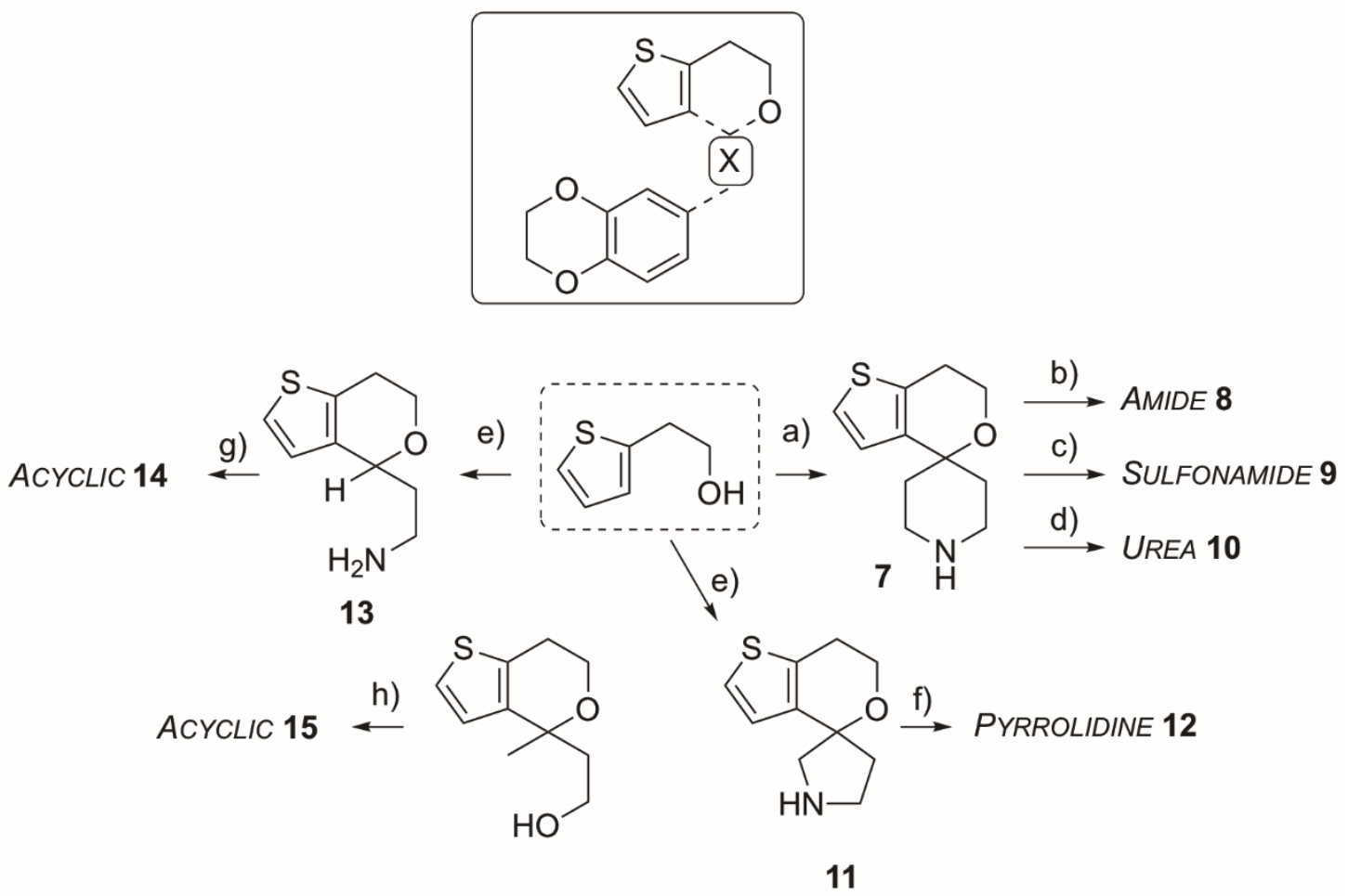

Reagents and Conditions: a) oxa-Pictet Spengler reaction, then deprotection. ${ }^{16}$ b) 1,4-benzodioxane-6-carboxylic acid, HOBt, EDCI, DCM, $20{ }^{\circ} \mathrm{C}, \mathrm{O} / \mathrm{N}$; c) 2,3-dihydrobenzo[b][1,4]dioxine-6-sulfonyl chloride, $\mathrm{Et}_{3} \mathrm{~N}, \mathrm{DCM}, 20$ ${ }^{\circ} \mathrm{C}, 2 \mathrm{~h}$; d) 6-isocyanato-2,3-dihydrobenzo[b][1,4]dioxine, DIPEA, DCM, $0{ }^{\circ} \mathrm{C}, 2 \mathrm{~h}$; e) (i) 3-pyrrolidinone, pTsOH $\cdot \mathrm{H}_{2} \mathrm{O}, \mathrm{Na}_{2} \mathrm{SO}_{4}, \mathrm{MeCN}, 82{ }^{\circ} \mathrm{C}, \mathrm{O} / \mathrm{N}$, (ii) TMSI, DCM, $20{ }^{\circ} \mathrm{C}, \mathrm{O} / \mathrm{N}$; f) 2,3-dihydro-1,4-benzodioxin-6carbaldehyde, Biotage ${ }^{\circledR}$ MP-cyanoborohydride, AcOH, DCM, MW, $100^{\circ} \mathrm{C}, 40$ min.; g) 2,3-dihydro-1,4- 
benzodioxin-6-carbaldehyde, ( $\mathrm{Ti}(\mathrm{OiPr})_{4}, \mathrm{EtOH}, \mathrm{rt}, 1 \mathrm{~h}$ then $\mathrm{NaBH}_{4}, 20{ }^{\circ} \mathrm{C}, 36$ h. h) (i) $\mathrm{MsCl}, \mathrm{Et}_{3} \mathrm{~N}, \mathrm{DCM}, 20$ ${ }^{\circ} \mathrm{C}, \mathrm{O} / \mathrm{N}$, (ii) 2,3-dihydro-1,4-benzodioxin-6-ylmethylamine, $\mathrm{Et}_{3} \mathrm{~N}, 75^{\circ} \mathrm{C}, \mathrm{O} / \mathrm{N}$.

Table 3. Evaluation of Analogs modified in the Central Part

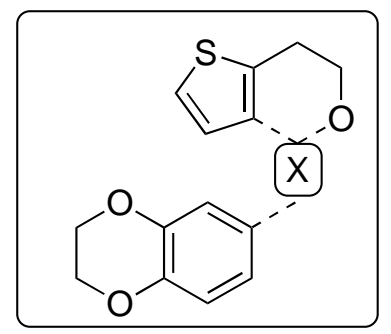

\begin{tabular}{|c|c|c|c|c|c|}
\hline Compound & $\mathbf{X}$ & $\begin{array}{c}\text { Mtb H37Rv } \\
\text { MIC90 }(\mu \mathrm{M})\end{array}$ & Compound & $\mathbf{X}$ & $\begin{array}{c}\text { Mtb H37Rv } \\
\operatorname{MIC90}(\mu \mathrm{M})\end{array}$ \\
\hline 1 & & 0.30 & 12 & & $>5$ \\
\hline 8 & & $>80$ & 14 & & $>5$ \\
\hline 9 & & $>10$ & 15 & & $>5$ \\
\hline 10 & & $>10$ & & & \\
\hline
\end{tabular}




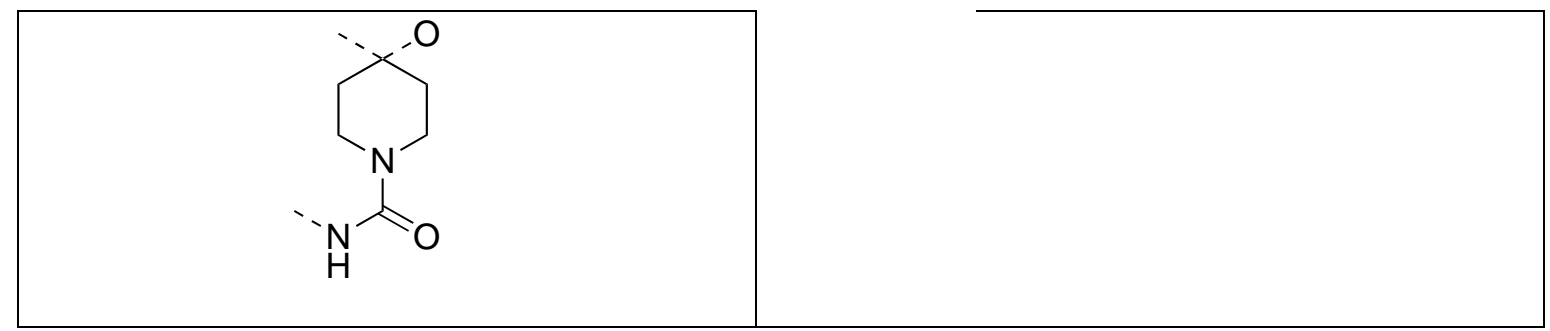

3) Modifications to the South. The southern area of the lead compound was examined through the synthesis of 25 compounds containing a modified $N$-substituent attached to the central 6',7'dihydrospiro[piperidine-4,4'-thieno[3,2-c]pyran by reductive amination (Scheme 3, Table 4). The aldehydes employed were either commercially available or easily synthesized by adapting methods already described in the literature. ${ }^{16,17}$

\section{Scheme 3. Synthesis of Compounds with Modifications to the Southern part}
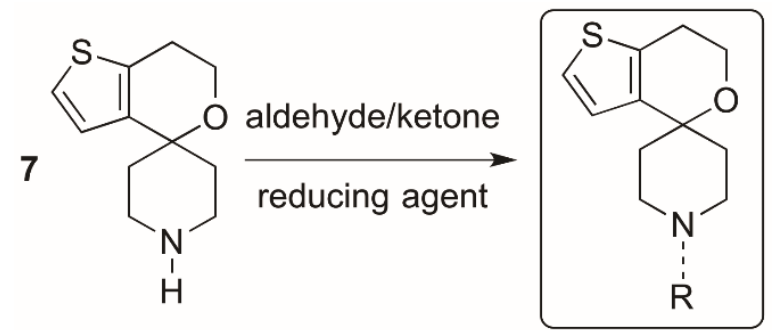

Reagents and Conditions: See Experimental Section and Supporting Information.

Table 4. Evaluation of Analogs modified in the Southern Part

\begin{tabular}{|c|c|c|c|c|}
\hline \multirow{2}{*}{ Compound } & \multirow{2}{*}{$\mathbf{R}$} & \multirow{2}{*}{$\begin{array}{l}\text { Mtb H37Rv } \\
\text { MIC90 }(\mu \mathrm{M})\end{array}$} & \multicolumn{2}{|c|}{$\mathrm{CL}_{\text {int }}(\mathrm{mL} / \mathrm{min} \cdot \mathrm{g})$} \\
\hline & & & human & mouse \\
\hline 1 & & 0.30 & 25 & $>30$ \\
\hline 7 & $\mathrm{H}$ & $>5$ & nd & nd \\
\hline 16 & & 0.23 & 2.9 & $>30$ \\
\hline
\end{tabular}




\begin{tabular}{|c|c|c|c|}
\hline 17 & 0.02 & 22.6 & $>30$ \\
\hline 18 & $>5$ & nd & nd \\
\hline $\mathbf{1 9}^{16}$ & $>5$ & nd & nd \\
\hline 20 & 0.20 & 22.5 & $>30$ \\
\hline 21 & 0.63 & 5.2 & $>30$ \\
\hline 22 & $>5$ & nd & nd \\
\hline 23 & 0.08 & 18.9 & $>30$ \\
\hline 24 & 0.02 & 9.9 & $>30$ \\
\hline 25 & 0.14 & 3.0 & 18.2 \\
\hline 26 & 0.63 & 4.6 & 18.1 \\
\hline 27 & 0.05 & 12.0 & 28.8 \\
\hline 28 & 0.12 & 1.9 & 1.1 \\
\hline
\end{tabular}




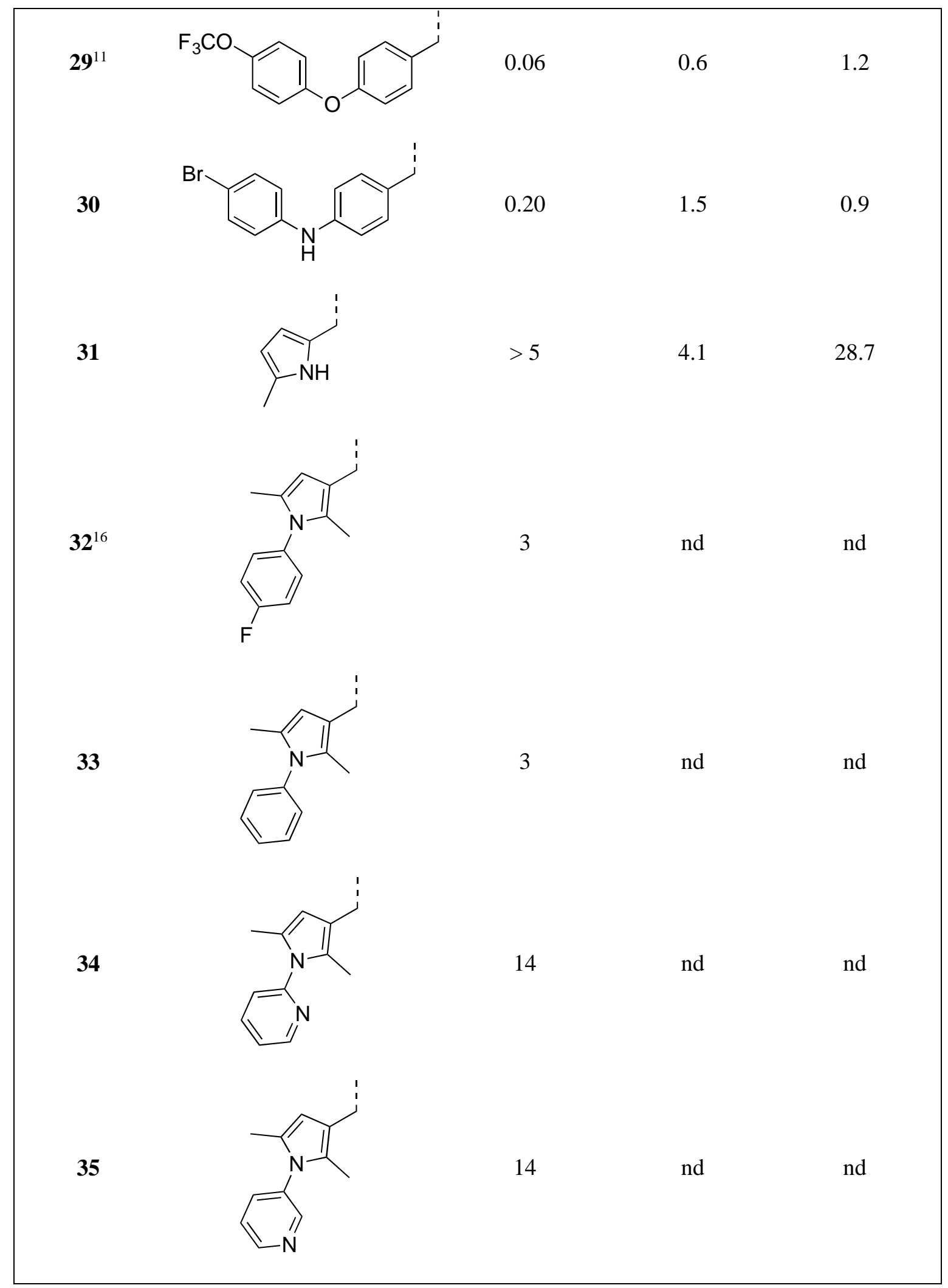




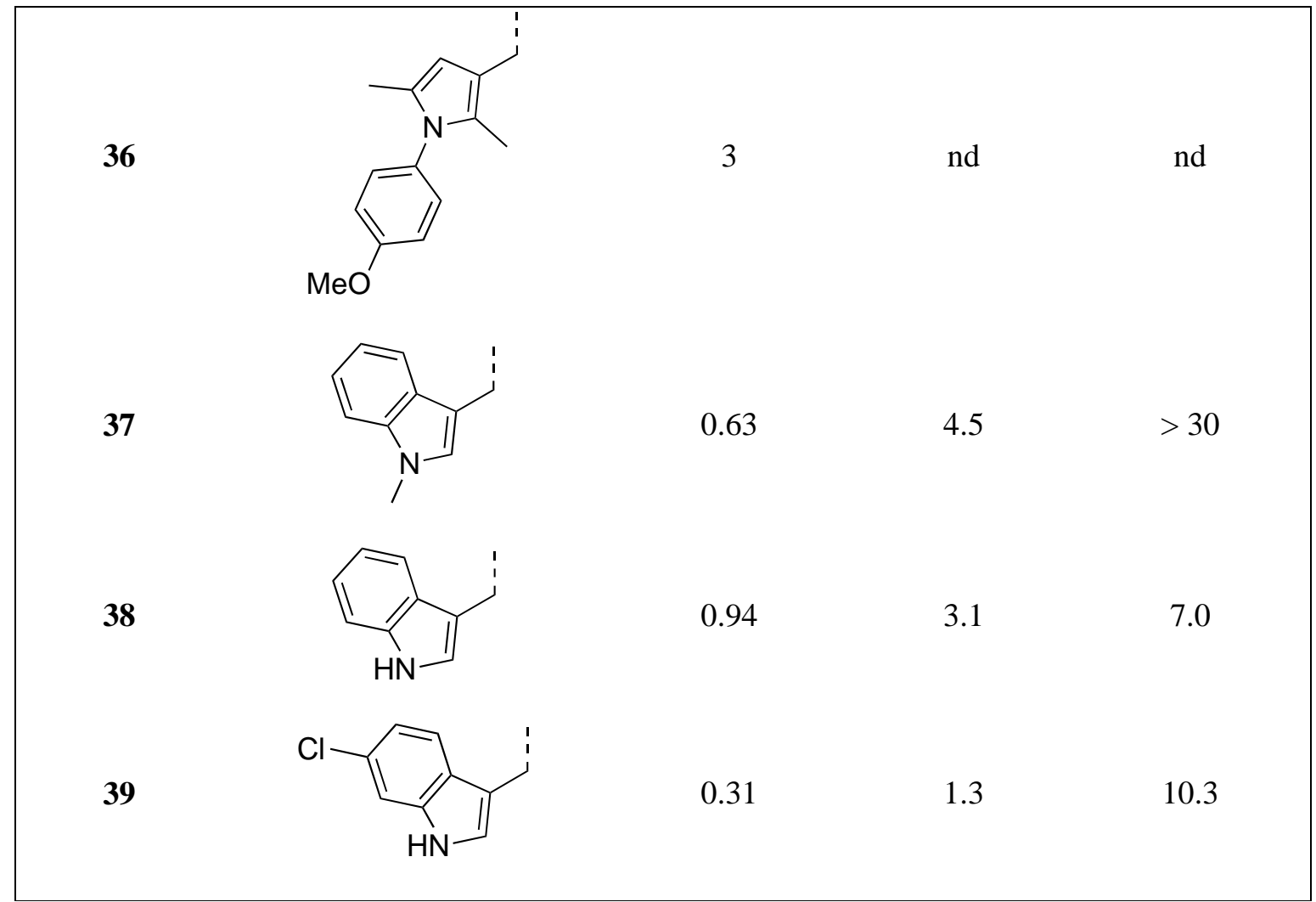

nd: not determined.

In general, placing aromatic rings in the south provided potent compounds ( $v s$. analog lacking substituents as in 7). However, there is a very high level of sensitivity to the substitution pattern, with the unsubstituted-benzyl compound 19 and the 2-methyl analogue 22 being inactive, whilst the 3- or 4-methyl isomers (20 and 21) and the 3,4-dimethyl (23) analogue were highly potent. The fused cyclohexyl (17) analogue was found to be more potent than the parent compound $\mathbf{1}$ or the corresponding chromane analogue 16, yet the pyridyl analogue (18) was found to be inactive. Several substituents were well tolerated in the 4-position of the phenyl ring $(\mathbf{2 4}, \mathbf{2 5})$, as was methyl branching in the benzylic position (26, racemic). Substitution of the phenyl ring for heterocyclic groups had varying effects, with the potency of the indole set (37-39) on the one hand, and the inactive pyrrole analogue $\mathbf{3 1}$ on the other. (Compound $\mathbf{3 1}$ was the least lipophilic analogue examined to this point; in order to evaluate the influence of polarity on metabolic stability this compound was, despite being inactive, progressed to the microsome assay but was found to be metabolically unstable.) Reasonable levels of potency were seen with a set of $N$-aryl pyrrole substitutions in this position $(\mathbf{3 2}, \mathbf{3 3}, \mathbf{3 6})$, although the $N$-pyridyl variants $(\mathbf{3 4}, \mathbf{3 5})$ were found to exhibit low potency. Biphenyl ether analogue 
27 displayed outstanding activity but microsomal clearance was still high. Blocking the para-position with hydroxymethyl, trifluoromethoxy and bromine substituents produced very potent and fairly stable compounds (28-30).

\section{Pharmacokinetics}

In order to confirm translation of the microsomal data to an in vivo setting, the pharmacokinetic profiles of the initial hit $\mathbf{1}$ and the di-aryl analogues (27-30) that gave the best results observed in vitro were selected for in vivo PK studies following a single dose administered through oral and intravenous routes (Table 5).

Table 5. In Vivo Pharmacokinetic Profile for Selected Compounds

\begin{tabular}{|c|c|c|c|c|c|c|c|c|c|}
\hline \multirow[b]{2}{*}{ Compound } & \multirow[b]{2}{*}{ Structure } & \multicolumn{4}{|c|}{ iv PK mice } & \multicolumn{4}{|c|}{ po PK mice } \\
\hline & & $\begin{array}{c}\text { Dose }^{\mathrm{a}} \\
(\mathrm{mg} / \mathrm{k} \\
\mathrm{g})\end{array}$ & $\mathbf{t}_{1 / 2}(\mathbf{h})$ & $\begin{array}{c}\text { Vss } \\
(\mathrm{L} / \mathrm{kg})\end{array}$ & $\begin{array}{c}\mathrm{Cl} \\
(\mathrm{mL} / \mathrm{m} \\
\mathrm{in} / \mathrm{kg})\end{array}$ & $\begin{array}{l}\text { Dose } \\
(\mathrm{mg} / \\
\mathrm{Kg})\end{array}$ & $\begin{array}{c}\text { Cmax } \\
(\mu \mathrm{g} / \mathrm{m} \\
\mathrm{L})\end{array}$ & $\begin{array}{c}\text { AUC } \\
(\mu \mathrm{g} \cdot \mathbf{h} / \\
\mathrm{mL})\end{array}$ & F (\%) \\
\hline 1 & & 4 & 0.7 & 7.4 & 214.2 & 49.2 & 0.47 & 1.78 & 14.6 \\
\hline 27 & & 3.6 & 3.9 & 19.4 & 67.7 & 18.7 & 0.05 & 0.10 & 1.5 \\
\hline 28 & & 3.9 & 0.2 & 7.0 & 721.8 & 44.0 & 0.04 & 0.04 & 2.5 \\
\hline 29 & & 3.8 & 3.2 & 10.4 & 36.3 & 44.0 & 1.27 & 8.74 & 42.6 \\
\hline 30 & & 4.5 & 7.3 & 12.0 & 19.8 & 45.0 & 1.02 & 17.87 & 84.6 \\
\hline
\end{tabular}


${ }^{a}$ For iv route, all compounds were administered in 5\% DMSO/20\% Encapsin; this was identified as a suitable vehicle to dissolve the compounds at the required dose.

In the in vitro studies, compound 27 displayed already high intrinsic clearance in liver microsomes. Consistently, the low bioavailability observed in the oral administration profile confirmed an extensive first-pass metabolism of the compound. Compound $\mathbf{2 8}$ contrasted the in vitro data and presented high in vivo clearance and low exposure following i.v. and p.o. administration, respectively. This result might be attributed to the enhanced intrinsic clearance likely due to phase II metabolism of the primary alcohol. In contrast, compounds $\mathbf{2 9}$ and $\mathbf{3 0}$ presented the best bioavailability with lower intrinsic clearance, longer half-lives and oral AUC values suitable for progression into efficacy studies. Cross-resistance of compound $\mathbf{2 9}$ with resistant mutants generated against initial hit $\mathbf{1}$ confirmed that, despite the structural changes incorporated during the optimization process, the biological target is maintained. ${ }^{11}$

\section{In vivo Efficacy}

The efficacy of compound $\mathbf{2 9}$, showing promising pharmacokinetic profile and high in vitro potency, was studied in an acute TB murine infection model. The data obtained are shown in Figure 2. Compound 29 proved to be very efficacious showing a -cidal response, $4.2 \log$ CFU reduction compared to the untreated control, similar to isoniazid. The good result obtained in a short assay in which the compound is administered only for 8 days is evidence for a fast-killing profile. ED ${ }_{99}$ (Efficacious Dose that gives $2 \log$ colony-forming units (CFU) reduction compared to the untreated control) was $11.6 \mathrm{mg} / \mathrm{kg}$. This encouraging value, although higher than that of isoniazid, is in the range of most existing antitubercular dugs. A maximum recommended dose of $50 \mathrm{mg} / \mathrm{kg}$ was used since tolerability issues had been observed at higher doses. The exciting results that confirmed the potential of this chemical series to efficiently kill Mtb in vivo prompted us to continue our medicinal chemistry efforts towards optimization of compound 29. 


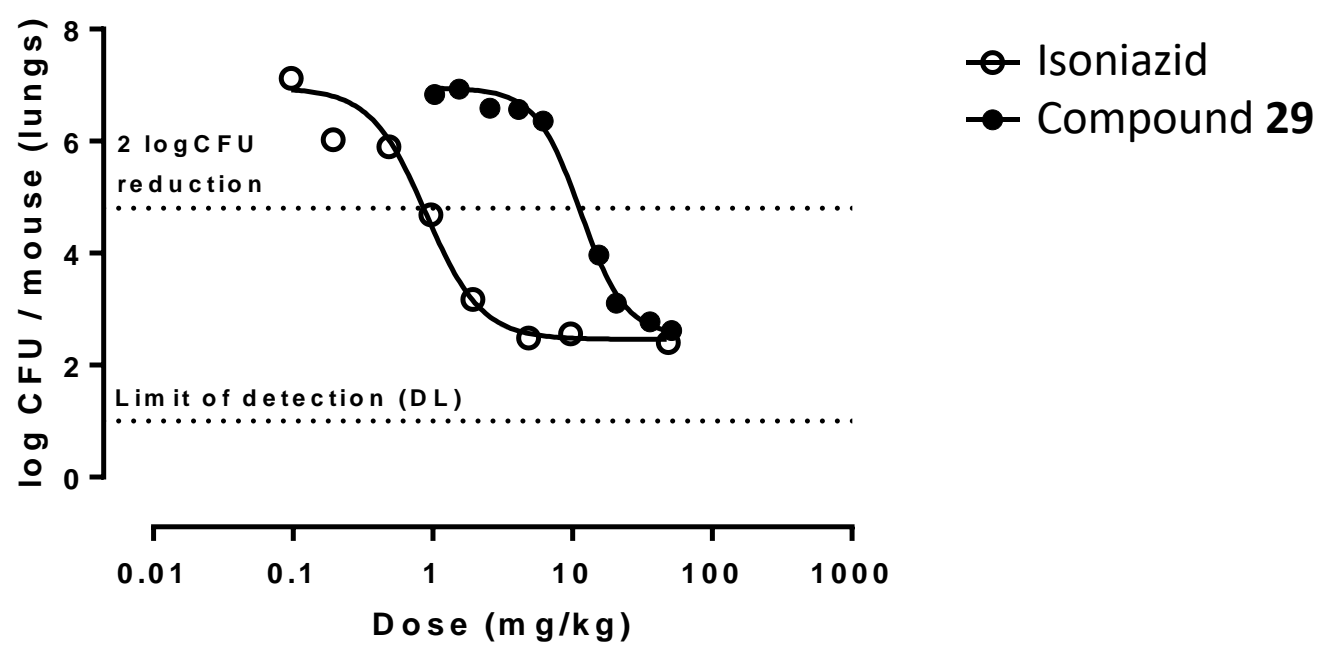

Figure 2. Efficacy in a mouse model of acute TB infection under oral QD dosing regimen (once a day). C57BL/6J mice were infected with M. tuberculosis $\mathrm{H} 37 \mathrm{Rv}$ intratracheally $\left(\sim 10^{5} \mathrm{CFU}\right)$ and were dosed starting on the following day after infection for 8 days. Mice were sacrificed at least $24 \mathrm{~h}$ after the last drug administration.

\section{Decreasing Lipophilicity}

Despite its remarkable efficacy, a number of factors precluded further progression of compound 29 (see Tables 6 and 7). The Cell Health $(\mathrm{CH})$ assay is a triple-readout phenotypic assay measuring changes in cell structure as a preliminary consequence of cytotoxic injury. The assay uses automated imaging to measure $\mathrm{IC}_{50}$ values for the effect of compounds on human liver-derived HepG2 cells (48 $\mathrm{h}$ incubation) as a surrogate of hepatotoxicity. For high doses (>100 mg/day), an $\mathrm{IC}_{50}$ value lower than $80 \mu \mathrm{M}$ in any of the readouts of the assay is considered an indication of high hepatotoxicity risk (see Table 6 for data of compound 29). Both high doses and long treatments, considered as an additional risk factor, are common to antitubercular drugs. Inhibition of the human ether-a-go-go-related gene (hERG) channel was also a concern for potential cardiotoxicity (see below and Table 7 for discussion). Additionally, the compound presented a poor solubility and high lipophilicity. We envisioned that a decrease of the latter would be a reasonable strategy to improve the general ADMET profile of compound 29. At this stage, we used the property forecast index (PFI), a more relevant measure of the lipophilicity of the compounds, to guide the design of new analogs. PFI is the sum of 
the Chrom LogD7.4 and the number of aromatic rings and values lower than 7 predict promising compounds in terms of solubility, permeation, cytochrome P450s, intrinsic clearance, and hERG binding and promiscuity. ${ }^{18}$ In an effort to reduce lipophilicity (compound 29 has a PFI value of $c a$. 12), several compounds lacking the thiophene ring were proposed that afforded improved predicted PFI values (Table 6); such changes had not previously been addressed in modifying the northern part of the molecule (Table 2).

Accordingly, these compounds (40-50) were synthesized (Scheme 4) by reductive amination of 4-[4(trifluoromethoxy)phenoxy]benzaldehyde or 4-tert-butylbenzaldehyde and the corresponding cyclic amines. The amines employed were either commercially available or easily synthesized. In the case of compounds 42 and 50, the spirocyclic amine (58) required was synthesized as shown in Scheme 5. The synthesis started with the Grignard reaction of $N$-Boc-4-piperidone with allylmagnesium bromide to form the corresponding alcohol $\mathbf{5 5}$, which was alkylated with allyl bromide to form ether $\mathbf{5 6}$. Ring closing metathesis of $\mathbf{5 6}$ with Grubbs I catalyst formed the unsaturated spirocyclic compound $\mathbf{5 7}$, which underwent hydrogenation followed by $N$-deprotection to form $\mathbf{5 8}$.

Scheme 4. Synthesis of Analogs Lacking the Thiophene Ring<smiles>[R]C1(C)CCN(Cc2ccc(Oc3ccc(OC(F)(F)F)cc3)cc2)CC1</smiles>

40-49

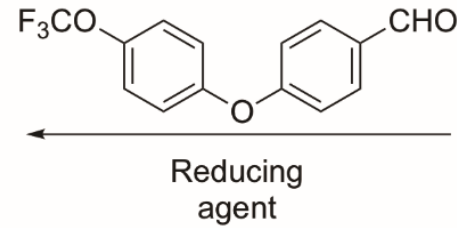

agent<smiles>[R]C1(C)CCNCC1</smiles>

$\mathrm{H}$

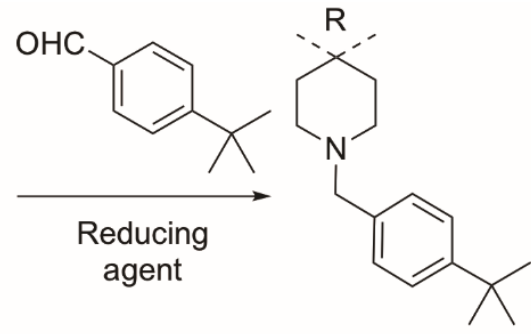

$50-54$

Scheme 5. Synthesis of 1-Oxa-9-azaspiro[5.5]undecane 


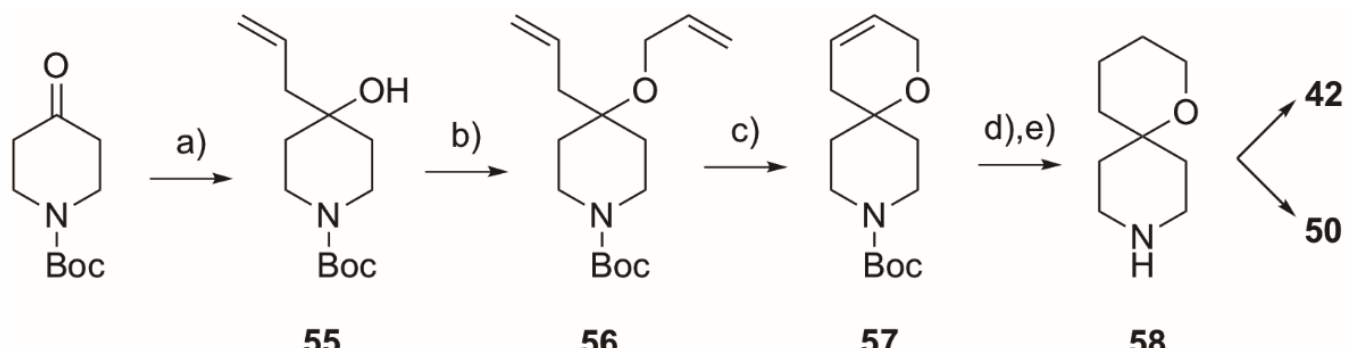

56

Reagents and Conditions: a) Allylmagnesium bromide, $\mathrm{Et}_{2} \mathrm{O}, 0^{\circ} \mathrm{C}$, then $20{ }^{\circ} \mathrm{C}, \mathrm{O} / \mathrm{N}$; b) allylbromide, $\mathrm{NaH}$, DMF, $20^{\circ} \mathrm{C}$; c) Grubbs I, DCM; d) $\mathrm{Pd} / \mathrm{C}, \mathrm{H}_{2}, \mathrm{MeOH}, \mathrm{Et}_{2} \mathrm{O}, 0^{\circ} \mathrm{C}$, then $20^{\circ} \mathrm{C}, \mathrm{O} / \mathrm{N}$; e) $3 \mathrm{M} \mathrm{HCl}, \mathrm{MeOH}, 2 \mathrm{~h}, 20$ ${ }^{\circ} \mathrm{C}$.

Table 6. Evaluation of Compounds Lacking the Thiophene Ring

\begin{tabular}{|c|c|c|c|c|c|c|c|}
\hline \multirow{2}{*}{ Cmpd } & \multirow{2}{*}{$\mathbf{R}$} & MIC & \multicolumn{2}{|c|}{$\mathrm{CL}_{\text {int }}(\mathrm{mL} / \mathrm{min} \cdot \mathrm{g})$} & \multirow{2}{*}{$\begin{array}{l}\text { Cell Health } \\
(\mathrm{A} / \mathrm{B} / \mathrm{C}, \boldsymbol{\mu M})^{\mathrm{a}}\end{array}$} & \multirow{2}{*}{$\begin{array}{c}\text { Solubility }^{b} \\
(\mu M)\end{array}$} & \multirow{2}{*}{ PFI } \\
\hline & & $(\mu \mathrm{M})$ & Human & Mouse & & & \\
\hline & & & & & & & \\
\hline 29 & & 0.06 & 0.6 & 1.2 & $12.6 / 10.7 / 11.0$ & 6 & 12.37 \\
\hline 40 & & $>5$ & nd & nd & $46.3 / 49.5 / 44.2$ & 156 & 9.17 \\
\hline 41 & & 0.10 & 0.5 & 2.8 & $28.3 / 21.8 / 25.9$ & $<1$ & 12.66 \\
\hline 42 & & 0.31 & 1.7 & 1.2 & $43.7 / 46.3 / 38.7$ & $<1$ & 9.91 \\
\hline 43 & & 0.65 & $<0.5$ & $<0.5$ & $25.7 / 28.8 / 26.3$ & 53 & 9.56 \\
\hline 44 & & $>5$ & nd & nd & $49.8 / 53.8 / 46.9$ & 52 & 9.68 \\
\hline 45 & & 1.3 & 1.5 & 0.6 & 132.6/140.9/96.9 & $\mathrm{Nd}$ & 9.79 \\
\hline
\end{tabular}




\begin{tabular}{|c|c|c|c|c|c|c|}
\hline 46 & $>5$ & nd & nd & $5.7 / 6.6 / 4.9$ & 117 & 6.21 \\
\hline 47 & $>5$ & nd & nd & $29.2 / 36.3 / 39.4$ & 87 & 8.91 \\
\hline 48 & $>5$ & nd & nd & $75.9 />200 / 74.1$ & 121 & 9.24 \\
\hline 49 & 2.5 & nd & nd & $8.0 / 12.2 / 6.9$ & 205 & 7.57 \\
\hline & & & & & & \\
\hline 50 & 0.21 & 3.2 & 18.1 & 157.7/134.6/129.0 & $\geq 596$ & 7.23 \\
\hline 51 & 0.63 & 7.3 & 48.0 & $>200 />200 />200$ & 363 & 7.23 \\
\hline 52 & 5 & 0.95 & 2.25 & $>200 />200 />200$ & $\geq 399$ & 6.56 \\
\hline 53 & 2.5 & 1.4 & 13.5 & $>200 />200 />200$ & 374 & 7.45 \\
\hline 54 & 5 & 4.1 & 27.0 & $>200 / 169.8 / 166.0$ & 194 & 8.80 \\
\hline
\end{tabular}

${ }^{\mathrm{a}} \mathrm{A}$ : membrane permeability; B: mitochondrial potential; C: nuclear morphology. ${ }^{\mathrm{b}}$ Kinetic solubility measured by CLND (see Experimental Section). nd: not determined.

The results indicated that activity is lost when the $\mathrm{R}$ group is just a hydrogen atom (the non-spiro compound 40). Cyclohexyl (41) and 2-pyranyl (42) groups, both lacking the fused thiophene ring, can be incorporated without significant detriment to the potency or stability, and with improved PFI 
(under 10) in the case of $\mathbf{4 2}$. Other more significant alterations to the pyran ring, such as the incorporation of a 6- or 5-membered ring acetal (43 and $\mathbf{4 4})$ or substitution with a 2-tetrahydrofuran ring (45), gave improved PFI and $\mathrm{CH}$ but higher MIC values, with clearance rates remaining low. Further changes incorporating amines $(\mathbf{4 6}, 49)$, an $\alpha, \beta$-unsaturated amide (47) and a lactone (48) gave compounds with good solubilities and PFI values (particularly in the case of 46) but with poor potency values. Compound $\mathbf{5 0}$, containing the 2-pyranyl moiety of $\mathbf{4 2}$, but with a 4-tert-butylphenyl ring in place of the bis-phenyl ether presented a good PFI value as two aromatic rings had been removed, showing at the same time good potency and solubility, reasonable human microsomal stability and low cytotoxicity. These trends continued for the related compounds containing isomeric pyrans $(\mathbf{5 1}, \mathbf{5 2})$ or ketals $(\mathbf{5 3}, \mathbf{5 4})$ which displayed excellent $\mathrm{CH}$ and PFI values alongside low clearance rates, but with generally lower potency than compound $\mathbf{5 0}$.

As mentioned above, the cardiovascular risk associated to hERG inhibition was also a concern that needed to be monitored so in vitro hERG data were generated for a selection of compounds (Table 7).

Table 7. In vitro Cardiovascular Data for Selected Compounds

\begin{tabular}{|c|c|c|c|c|c|}
\hline Compound & Structure & PFI & $\begin{array}{c}\text { hERG } \\
\text { IW IC } \text { IC }_{50} \\
(\mu M)\end{array}$ & $\begin{array}{r}\text { hERG PXP } \\
\text { IC }_{50}(\mu M)^{\mathrm{a}}\end{array}$ & In silico \\
\hline 29 & & 12.37 & 10.0 & $1.5(98.4)$ & hERG alert \\
\hline 30 & & 10.39 & 7.9 & $2.3(93.2)$ & hERG alert \\
\hline
\end{tabular}




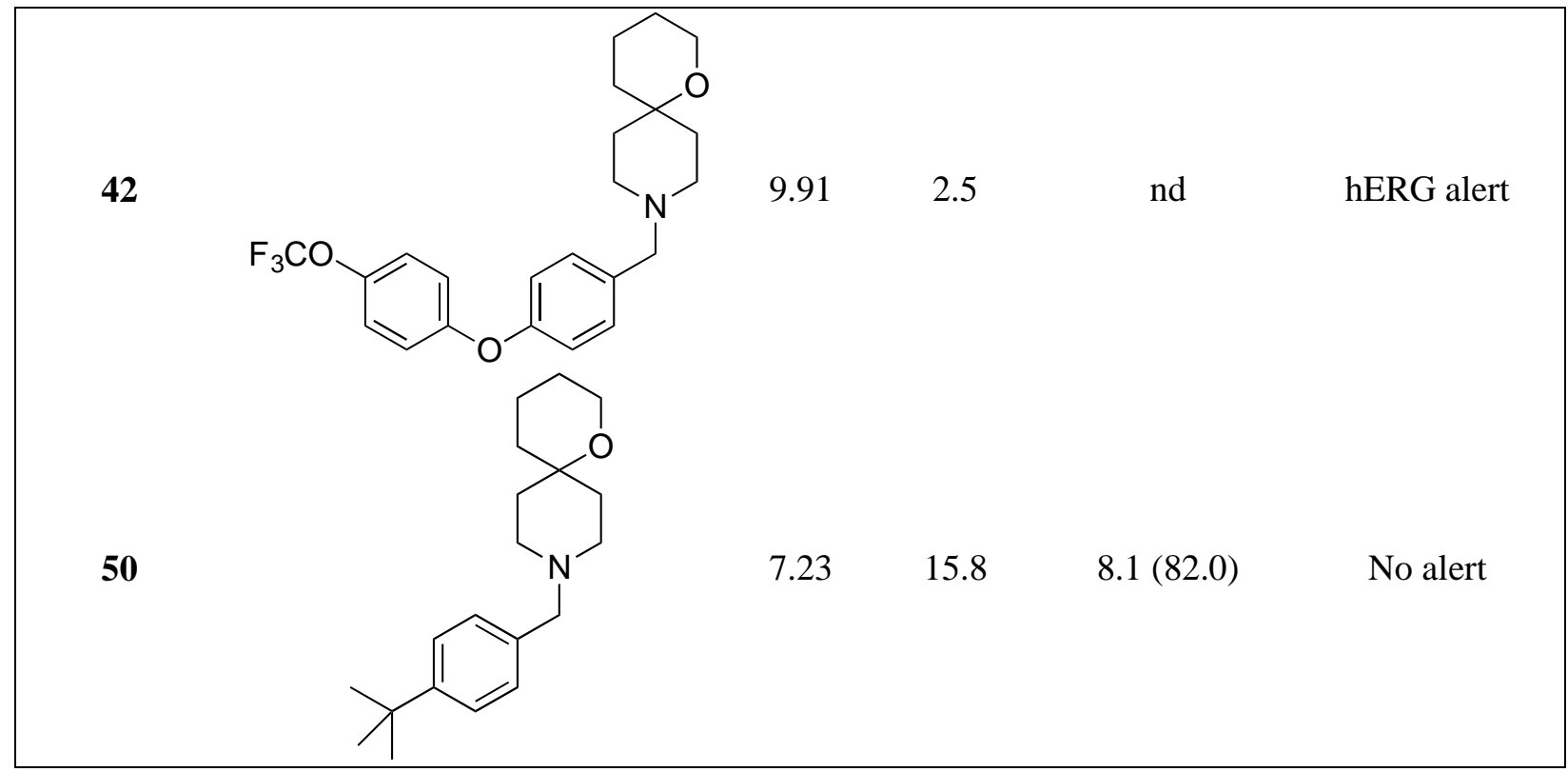

${ }^{a}$ Maximum inhibition (\%) indicated in brackets. nd: not determined.

The in silico prediction from the structures pointed to potential hERG channel inhibition in vitro in mammals for compounds 29, 30 and 42. This alert describes a structure-based pharmacophore developed primarily from compounds that have been reported to be strong inhibitors of the hERG potassium channel. ${ }^{18}$ An ion channel inhibition in vitro assay, carried out using automated planar chip electrophysiology platforms IonWorks (IW) and PatchExpress (PXP), confirmed the alert. Although the less lipophilic compound $\mathbf{5 0}$ did not show an in silico alert, the experimental hERG inhibition was decreased by less than one order of magnitude. We decided to assess if the cardiovascular liability of the series was also observed in ex vivo studies (perfused rabbit ventricular wedge assay, RVW) with compound $\mathbf{5 0}$ (Table 8).

Table 8. Rabbit Ventricular Wedge Data for Compound 50

\begin{tabular}{|ccccc|}
\hline Compound & $\begin{array}{c}\text { QT }(\boldsymbol{\mu M}) \\
(\% \text { change })\end{array}$ & $\begin{array}{c}\text { QRS }(\boldsymbol{\mu M}) \\
(\boldsymbol{\%} \text { change })\end{array}$ & $\begin{array}{c}\text { Tp-e }(\boldsymbol{\mu M}) \\
(\% \text { change })\end{array}$ & TdP score $@ \mathbf{1 0 \mu M}$ \\
\hline $\mathbf{5 0}$ & $10(12.2)$ & $30(25.4)$ & $10(44.4)$ & 3.0 \\
\hline
\end{tabular}

${ }^{a}$ TdP score $>2.5$ predicts a risk of cardiovascular toxicity. 
Compound $\mathbf{5 0}$ caused a concentration-dependent prolongation of QT interval and Tp-e from $10 \mu \mathrm{M}$ and also caused a prolongation of QRS interval from $30 \mu \mathrm{M}$. The maximum Torsades de Pointes (TdP) score ${ }^{19}$ was 3.0 at $10 \mu \mathrm{M}$ that exceed the 2.5 threshold (based on GSK criteria) indicating a risk of developing TdP arrhythmias. These results confirm the cardiovascular risk associated to this chemical series.

Furthermore, in vivo tolerability studies (data not shown) suggested that $\mathbf{5 0}$ presented a maximum tolerated exposure lower than that of compound 29: AUC $<6.6 \mu \mathrm{g} \cdot \mathrm{h} / \mathrm{mL}$ for $\mathbf{5 0} v s .13 .7 \mu \mathrm{g} \cdot \mathrm{h} / \mathrm{mL}$ for 29. It is evident that in this case the considerable reduction of lipophilicity (almost 5 units of PFI) and simplification of the structure (MW reduced from 475.5 to 301.5 ) achieved in the optimization process that led from compound $\mathbf{2 9}$ to $\mathbf{5 0}$ afforded only a modest improvement in hERG in vitro data and no progress in terms of in vivo tolerability. At this point, despite the excellent efficacy observed with this chemical class, we considered that the associated safety risk was high and decided to discontinue our work on the series.

\section{CONCLUSIONS}

Through exploration of a class of small molecule spirocyclic compounds, made easier by the ease with which the compounds can be accessed synthetically, we have identified highly potent antitubercular compounds. Several compounds examined possessed good pharmacokinetic properties. Most importantly, a representative member of the series displayed remarkable potency in an in vivo model of the disease. These features would normally mark the series out as highly promising for further investigation, but a significant risk of hERG inhibition and a lower-than-desired in vivo tolerability have combined to lead us to park the series. There may be ways to engineer around these series liabilities and members of the broader drug discovery community may discover such solutions. To encourage collaboration with an open source research mechanism, the data and related materials for the series are posted on a community resource created for this purpose,${ }^{20}$ adopting principles that have driven open source research mechanisms in other disease areas. ${ }^{17 \mathrm{c}}$ Any scientist interested in furthering this series, or adopting an open approach to other series, is encouraged to do so using this free online infrastructure. 


\section{EXPERIMENTAL SECTION}

We can confirm that all animal studies were ethically reviewed and carried out in accordance with European Directive 2010/63/EU and the GSK Policy on the Care, Welfare and Treatment of Animals. Compound synthesis. All commercially available reagents and solvents were used without further purification. High performance liquid chromatography (HPLC) was used to determine the purity of the compounds synthesized. The data confirmed that the target compounds generally had $\geq 95 \%$ of purity with the exception of compounds 14 (90\%), 18 (91\%), 23 (90\%), 36 (90\%) and 47 (85\%). When reactions were performed under microwave conditions, a Biotage Initiator was used. The yields refer to the purified products, and they were not optimized. Reactions were monitored by TLC on silica gel with detection by UV light $(254 \mathrm{~nm})$ and/or stained with the relevant reagent. TLC analysis was performed using Merck Silica Gel 60 F254 precoated aluminium plates $(0.2 \mathrm{~mm})$ or Polygram precoated silica gel TLC sheets SIL G/UV254. When necessary, crude reaction products were purified by using flash chromatography, ion exchange purifications and/or preparative HPLC. Flash purifications were usually performed on a Biotage ISOLERA One flash system equipped with an internal variable dual wavelength diode array detector (200-400 nm). SNAP cartridges (10-100 g, flow rate of $10-100 \mathrm{~mL} / \mathrm{min}$ ) were used. Dry sample loading was done by selfpacking samplet cartridges using silica or Celite 545. Gradients used varied for each purification. However, typical gradients used for normal phase were gradients of $0-100 \%$ ethyl acetate in cyclohexane or $0-15 \%$ methanol in $\mathrm{CH}_{2} \mathrm{Cl}_{2}$. For Ion-exhange purifications, SOLUTE® SCX-2 Ion-exchange columns (1-50 g) were used with elutions of $\mathrm{MeOH}$ followed by $7 \mathrm{~N} \mathrm{NH}_{3}$ in $\mathrm{MeOH}$. Purification using prep-HPLC was accomplished using a Gilson HPLC system with a Gemini $5 \mu \mathrm{m} \mathrm{C18}$ column $(150 \mathrm{~mm} \times 21.2$ $\mathrm{mm}$ i.d.). Typically, the mobile phase used for HPLC was a linear gradient of water (A) and acetonitrile (B). The water and acetonitrile were mixed with $0.1 \%$ TFA or $0.1 \% \mathrm{HCOOH}$. The flow rate was maintained at $0.8-1.2 \mathrm{~mL} / \mathrm{min}$ for analytic HPLC and $20 \mathrm{~mL} / \mathrm{min}$ for prep-HPLC, and the eluent was monitored with UV detector at $220 \mathrm{~nm}$. Characterization of all final compounds was performed using ${ }^{1} \mathrm{H}$ NMR spectroscopy and mass spectrometry. ${ }^{1} \mathrm{H}$ NMR spectra were recorded at 300K on Bruker spectrometers: either an AVANCE $300\left({ }^{1} \mathrm{H}\right.$ at $\left.300 \mathrm{MHz}\right)$, AVANCE $200\left({ }^{1} \mathrm{H}\right.$ at 200 
$\mathrm{MHz})$ or Ultrashield DPX 400 spectrometer $\left({ }^{1} \mathrm{H}\right.$ at $\left.400 \mathrm{MHz}\right)$. Chemical shifts $(\delta)$ are given in ppm relative to the solvent reference as an internal standard $\left(\mathrm{d}_{6}-\mathrm{DMSO}, \delta=2.50 \mathrm{ppm} ; \mathrm{CDCl}_{3}, \delta=7.27\right.$ ppm; $\mathrm{CD}_{3} \mathrm{OD}, \delta=3.31 \mathrm{ppm}$ ). Data are reported as follows: chemical shift (multiplicity (s for singlet, $\mathrm{d}$ for doublet, $\mathrm{t}$ for triplet, $\mathrm{m}$ for multiplet, br for broad), integration, coupling constant(s) in Hz. Lowresolution mass spectrometry $(\mathrm{m} / \mathrm{z})$ was carried out on a Finnigan quadrupole ion trap mass spectrometer using electrospray ionisation (ESI) or atmospheric-pressure chemical ionisation (APCI) or Agilent LC-MS 1200 with 6110 MS detector. Positive and negative detection is indicated by the charge of the ion, e.g. $[\mathrm{M}+\mathrm{H}]^{+}$indicates positive ion detection. The purities of the final compounds were $\geq 95 \%$ unless stated otherwise, as determined by Agilent 1100 instrument equipped with a Sunfire C18 column ( $30 \mathrm{~mm} \times 2.1 \mathrm{~mm}$ i.d., $3.5 \mathrm{~mm}$ packing diameter) at $40{ }^{\circ} \mathrm{C}$ coupled with a Waters ZMD2000 mass spectrometer; the method of ionization was alternate-scan positive and negative electrospray. The following section comprises the synthetic procedures for some representative intermediates and several products reported in this publication. Complementary data for the rest of intermediates and final compounds can be found in the Supporting Information.

\section{General Procedure A. Reductive amination}

A solution of secondary amine (1 equiv) and the appropriate aldehyde (1-1.1 equiv) in $\mathrm{CH}_{2} \mathrm{Cl}_{2}$ or DCE (molarity $0.05-0.14 \mathrm{M}$ ) was stirred at $\mathrm{rt}$ for $1-4 \mathrm{~h}$. Sodium triacetoxyborohydride or solidsupported Amberlite ${ }^{\circledR}$ IRA-900 cyanoborohydride (1-6 equiv) was added and the reaction was stirred at room temperature or $40-100{ }^{\circ} \mathrm{C}$ for $1.5-48 \mathrm{~h}$. After allowing to cool, the reaction was quenched by addition of saturated $\mathrm{NaHCO}_{3}$ solution and extracted with $\mathrm{CH}_{2} \mathrm{Cl}_{2}$, the organic layer was dried $\left(\mathrm{Na}_{2} \mathrm{SO}_{4}\right)$, filtered and concentrated to afford a crude mixture that was purified by column chromatography and/or preparative HPLC to give the corresponding tertiary amine.

\section{General Procedure B. Reductive amination}

A solution of secondary amine (1 equiv), the appropriate aldehyde (1-1.1 equiv), Biotage ${ }^{\circledR}$ MPCyanoborohydride (1.7 equiv) or solid-supported Amberlite ${ }^{\circledR}$ IRA-900 cyanoborohydride (1-1.7 equiv) and acetic acid (4 equiv) in $\mathrm{CH}_{2} \mathrm{Cl}_{2}$ (molarity $0.06-0.16 \mathrm{M}$ ) was subjected to $\mathrm{MW}$ irradiation for $40-180 \mathrm{~min}$ at $100{ }^{\circ} \mathrm{C}$. The reaction was filtered, quenched by addition of saturated $\mathrm{NaHCO}_{3}$ solution and extracted with $\mathrm{CH}_{2} \mathrm{Cl}_{2}$. The organic layer was dried $\left(\mathrm{Na}_{2} \mathrm{SO}_{4}\right)$, filtered and concentrated 
to afford a crude mixture that was purified by column chromatography or preparative HPLC to give the corresponding tertiary amine.

\section{1-(4-Phenoxybenzyl)-6',7'-dihydrospiro[piperidine-4,4'-thieno[3,2-c]pyran] (27)}

The title compound was prepared using General Procedure A. White solid, yield 80\% (600 mg, 1.532 mmol). ${ }^{1} \mathrm{H}$ NMR (400 MHz, $\left.\mathrm{CDCl}_{3}\right) \delta$ ppm: 7.36-7.31 (m, 4H), 7.12-7.07 (m, 2H), 7.04-6.94 (m, $4 \mathrm{H}), 6.83(\mathrm{~d}, 1 \mathrm{H}, J=5.3), 3.95-3.93(\mathrm{~m}, 2 \mathrm{H}), 3.54(\mathrm{~s}, 2 \mathrm{H}), 2.85-2.82(\mathrm{~m}, 2 \mathrm{H}), 2.76-2.73(\mathrm{~m}, 2 \mathrm{H})$, 2.43-2.38 (m, 2H), 2.03-1.95 (m, 2H), 1.89-1.84 (m, 2H). [ES+ MS] m/z $392(\mathrm{M}+\mathrm{H})^{+}$.

\section{(4-(4-((6',7'-Dihydrospiro[piperidine-4,4'-thieno[3,2-c]pyran]-1-}

\section{yl)methyl)phenoxy)phenyl)methanol, hydrochloride (28)}

The compound as a free amine was obtained using General Procedure A with 28a (see Supporting Information) as colorless oil. The compound as a free amine $(11.8 \mathrm{mg}, 0.028 \mathrm{mmol})$ was dissolved in $\mathrm{CH}_{2} \mathrm{Cl}_{2}(1.0 \mathrm{~mL})$ and $1 \mathrm{M} \mathrm{HCl}$ in $\mathrm{Et}_{2} \mathrm{O}(0.034 \mathrm{~mL}, 0.034 \mathrm{mmol})$ was added. After stirring at $\mathrm{rt}$ for 10 min, the solvent was evaporated to obtain the hydrochloride salt of the compound. White solid, yield $10 \%$ (12.8 mg, $0.028 \mathrm{mmol}) .{ }^{1} \mathrm{H}$ NMR (400 MHz, $\left.\mathrm{CDCl}_{3}+\mathrm{CD}_{3} \mathrm{OD}\right) \delta \mathrm{ppm:} 7.40-7.38(\mathrm{~m}, 2 \mathrm{H}), 7.21-$ $7.19(\mathrm{~m}, 2 \mathrm{H}), 6.96(\mathrm{~d}, 1 \mathrm{H}, J=5.3), 6.86-6.84(\mathrm{~m}, 4 \mathrm{H}), 6.75(\mathrm{~d}, 1 \mathrm{H}, J=5.1), 4.45(\mathrm{~s}, 2 \mathrm{H}), 4.03(\mathrm{~s}, 2 \mathrm{H})$, 3.20-3.14 (m, 4H), 3.06-3.00 (m, 2H), 2.68-2.66 (m, 2H), 2.44-2.37 (m, 2H), 1.87-1.83 (m, 2H). $[\mathrm{ES}+\mathrm{MS}] \mathrm{m} / \mathrm{z} 422(\mathrm{M}+\mathrm{H})^{+}$.

\section{4-Bromo-N-(4-((6',7'-dihydrospiro[piperidine-4,4'-thieno[3,2-c]pyran]-1-}

\section{yl)methyl)phenyl)aniline, hydrochloride (30)}

The compound as a free amine was obtained using the general procedure B with $\mathbf{3 0 b}$ (see Supporting Information) as colorless oil. The compound as a free amine (480 mg, $1.02 \mathrm{mmol}$ ) was dissolved in $\mathrm{CH}_{2} \mathrm{Cl}_{2}(3 \mathrm{~mL})$ and treated with $2 \mathrm{M} \mathrm{HCl}$ in $\mathrm{Et}_{2} \mathrm{O}(0.51 \mathrm{~mL}, 1.02 \mathrm{mmol})$. The precipitate was filtered and washed with $\mathrm{CH}_{2} \mathrm{Cl}_{2}$, hexane and acetonitrile to afford the title compound as a pink solid, yield 59\% (446 mg, $0.873 \mathrm{mmol}$ ). ${ }^{1} \mathrm{H}$ NMR (400 MHz, DMSO- $\left.d_{6}\right) \delta$ ppm: 10.49 (bs, $\left.1 \mathrm{H}\right), 8.59(\mathrm{~s}, 1 \mathrm{H})$, 7.47-7.36 (m, 4H), $7.36(\mathrm{~d}, 1 \mathrm{H}, J=5.1), 7.12-7.05(\mathrm{~m}, 4 \mathrm{H}), 6.77$ (d, 1H, J=5.3), 4.24 (bd, 2H, J=5.1), 3.88 (bt, 2H, J=5.1), 3.25-3.22 (m, 2H), 3.14-3.06 (m, 2H), 2.78 (bt, 2H, $J=5.1), 2.38-2.30(\mathrm{~m}, 2 \mathrm{H})$, $1.98-1.95(\mathrm{~m}, 2 \mathrm{H}) .[\mathrm{ES}+\mathrm{MS}] \mathrm{m} / \mathrm{z} 469(\mathrm{M}+\mathrm{H})^{+}$. 
9-(4-(4-(Trifluoromethoxy)phenoxy)benzyl)-1-oxa-9-azaspiro[5.5]undecane, hydrochloride (42)

The compound as a free amine $(91 \mathrm{mg}, 0.218 \mathrm{mmol})$ was obtained using General Procedure A and 58 as a pale yellow oil. The compound as a free amine was dissolved in $\mathrm{CH}_{2} \mathrm{Cl}_{2}(5 \mathrm{~mL})$ and $1 \mathrm{M} \mathrm{HCl}$ in $\mathrm{Et}_{2} \mathrm{O}(0.218 \mathrm{~mL}, 0.218 \mathrm{mmol})$, the solvent was evaporated to obtain the hydrochloride salt of the compound. White solid, yield 47\% (100 mg, $0.218 \mathrm{mmol}) .{ }^{1} \mathrm{H}$ NMR (400 MHz, DMSO- $\left.d_{6}\right) \delta$ ppm: 10.41 (bs, $1 \mathrm{H}), 7.71$ (d, 2H, $J=8.5), 7.50$ (d, 2H, $J=8.5), 7.23$ (d, 2H, $J=9.0), 7.19$ (d, 2H, $J=9.0), 4.35$ (d, 2H, J=5.3), 3.64-3.62 (m, 2H), 3.24-3.19 (m, 2H), 3.10-3.01 (m, 2H), 2.16-2.13 (m, 2H) 1.81$1.74(\mathrm{~m}, 2 \mathrm{H}), 1.64-1.62(\mathrm{~m}, 2 \mathrm{H}), 1.52-1.50(\mathrm{~m}, 2 \mathrm{H}), 1.47-1.44(\mathrm{~m}, 2 \mathrm{H}) .[\mathrm{ES}+\mathrm{MS}] \mathrm{m} / \mathrm{z} 422(\mathrm{M}+\mathrm{H})^{+}$.

\section{9-(4-(tert-Butyl)benzyl)-1-oxa-9-azaspiro[5.5]undecane, hydrochloride (50)}

The compound as a free amine $(53.7 \mathrm{mg}, 0.178 \mathrm{mmol})$ was obtained using General Procedure A with 58. The compound was dissolved in $\mathrm{CH}_{2} \mathrm{Cl}_{2}(5 \mathrm{~mL})$ and $1 \mathrm{M} \mathrm{HCl}$ in $\mathrm{Et}_{2} \mathrm{O}(178 \mu \mathrm{L}, 0.178 \mathrm{mmol})$. The solvent was evaporated to obtain the hydrochloride salt of the compound. White solid, yield 38\% (60 mg, $0.178 \mathrm{mmol}) .{ }^{1} \mathrm{H}$ NMR (400 MHz, DMSO- $\left.d_{6}\right) \delta$ ppm: 10.30 (bs, $\left.1 \mathrm{H}\right), 7.59(\mathrm{~d}, 2 \mathrm{H}, J=8.5), 7.52$ (d, 2H, J=8.5), $4.31(\mathrm{~d}, 2 \mathrm{H}, J=5.3), 3.63-3.61(\mathrm{~m}, 2 \mathrm{H}), 3.21-3.17(\mathrm{~m}, 2 \mathrm{H}), 3.09-3.00(\mathrm{~m}, 2 \mathrm{H}), 2.15-$ $2.12(\mathrm{~m}, 2 \mathrm{H}) 1.80-1.72(\mathrm{~m}, 2 \mathrm{H}), 1.65-1.62(\mathrm{~m}, 2 \mathrm{H}), 1.51-1.49(\mathrm{~m}, 2 \mathrm{H}), 1.46-1.42(\mathrm{~m}, 2 \mathrm{H}), 1.36(\mathrm{~s}$, 9H). [ES+ MS] m/z $302(\mathrm{M}+\mathrm{H})^{+}$.

\section{tert-Butyl 4-allyl-4-hydroxypiperidine-1-carboxylate (55)}

Allylmagnesium bromide in $\mathrm{Et}_{2} \mathrm{O}(1 \mathrm{M}, 29.1 \mathrm{~mL}, 29.1 \mathrm{mmol})$ was slowly added to a solution of tertbutyl 4-oxopiperidine-1-carboxylate $(5.0 \mathrm{~g}, 25.1 \mathrm{mmol})$ in $\mathrm{Et}_{2} \mathrm{O}(80 \mathrm{~mL})$ at $0^{\circ} \mathrm{C}$. The reaction mixture was allowed to warm to $\mathrm{rt}$ overnight. The reaction was quenched by addition of saturated $\mathrm{NH}_{4} \mathrm{Cl}$ solution and the organic layer was separated, dried $\left(\mathrm{Na}_{2} \mathrm{SO}_{4}\right)$, filtered and evaporated to obtain a yellow oil (4.9 g). A fraction of crude (2 g) was purified by flash chromatography to obtain the title compound. Pale yellow oil, yield 45\% (1.1 g, $4.56 \mathrm{mmol}) .{ }^{1} \mathrm{H} \mathrm{NMR}\left(400 \mathrm{MHz}, \mathrm{CDCl}_{3}\right) \delta \mathrm{ppm}$ : 5.92$5.81(\mathrm{~m}, 1 \mathrm{H}), 5.23-5.13(\mathrm{~m}, 2 \mathrm{H}), 3.82-3.77(\mathrm{~m}, 2 \mathrm{H}), 3.17-3.14(\mathrm{~m}, 2 \mathrm{H}), 2.24(\mathrm{~d}, 2 \mathrm{H}, J=7.5), 1.56-$ $1.52(\mathrm{~m}, 4 \mathrm{H}), 1.46(\mathrm{~s}, 9 \mathrm{H})$.

\section{tert-Butyl 4-allyl-4-(allyloxy)piperidine-1-carboxylate (56)}

Allylbromide (1.082 mL, $12.43 \mathrm{mmol})$ was added to a solution of $\mathbf{5 5}(1.0 \mathrm{~g}, 4.1 \mathrm{mmol})$ in DMF (20 $\mathrm{mL})$ at $0^{\circ} \mathrm{C}$. After $5 \mathrm{~min}, \mathrm{NaH}(0.167 \mathrm{~g}, 6.63 \mathrm{mmol})$ was added. The reaction mixture was allowed to 
warm to $\mathrm{rt}$ and stirred for $48 \mathrm{~h}$. The reaction mixture was portioned between water and TBME. The organic layer was separated, washed with water $(3 \times 20 \mathrm{~mL})$, dried $\left(\mathrm{MgSO}_{4}\right)$ and concentrated. The crude product was purified by flash chromatography to afford the title compound. Pale yellow oil, yield 67\% (780 mg, $2.77 \mathrm{mmol}) .{ }^{1} \mathrm{H}$ NMR $\left(400 \mathrm{MHz}, \mathrm{CDCl}_{3}\right) \delta \mathrm{ppm}: 5.98-5.88(\mathrm{~m}, 1 \mathrm{H}), 5.86-5.75$ (m, 1H), 5.34-5.28 (m, 1H), 5.17-5.05 (m, 3H), 3.97-3.89 (m, 2H), 3.79-3.77 (m, 2H), 3.11-3.07 (m, 2H), $2.28(\mathrm{~d}, 2 \mathrm{H}, J=6.9), 1.79-1.75(\mathrm{~m}, 2 \mathrm{H}), 1.46(\mathrm{~s}, 9 \mathrm{H}), 1.43-1.40(\mathrm{~m}, 2 \mathrm{H})$.

\section{tert-Butyl 1-oxa-9-azaspiro[5.5]undec-3-ene-9-carboxylate (57)}

A solution of Grubbs I $(114 \mathrm{mg}, 0.139 \mathrm{mmol})$ in $\mathrm{CH}_{2} \mathrm{Cl}_{2}(10 \mathrm{~mL})$ under argon atmosphere was slowly added to a solution of $\mathbf{5 6}(780 \mathrm{mg}, 2.77 \mathrm{mmol})$ in $\mathrm{CH}_{2} \mathrm{Cl}_{2}(15 \mathrm{~mL})$ at $0{ }^{\circ} \mathrm{C}$. The reaction mixture was allowed to warm to rt and stirred overnight. The reaction was concentrated and the crude was purified by flash chromatography to afford the title compound. Pale brown oil, yield 95\% (670 mg, 2.64 mmol). ${ }^{1} \mathrm{H}$ NMR (400 MHz, $\left.\mathrm{CDCl}_{3}\right) \delta \mathrm{ppm}: 5.78-5.68(\mathrm{~m}, 2 \mathrm{H}), 4.12-4.10(\mathrm{~m}, 2 \mathrm{H}), 3.79-3.73$ (m, 2H), 3.19-3.17 (m, 2H), 1.98-1.96 (m, 2H), 1.81-1.78 (m, 2H), $1.46(\mathrm{~s}, 9 \mathrm{H}), 1.43-1.40(\mathrm{~m}, 2 \mathrm{H})$.

\section{1-Oxa-9-azaspiro[5.5] undecane, hydrochloride (58)}

$\mathrm{Pd} / \mathrm{C}(281 \mathrm{mg}, 0.264 \mathrm{mmol})$ was added to a solution of $57(670 \mathrm{mg}, 2.64 \mathrm{mmol})$ in $\mathrm{MeOH}(15 \mathrm{~mL})$. The reaction was hydrogenated at 2.5 bar for $2 \mathrm{~h}$. The reaction was filtered over Celite ${ }^{\circledR}$ and concentrated to afford the free amine. Off-white solid, yield 97\% (658 mg, $2.58 \mathrm{mmol}) .{ }^{1} \mathrm{H}$ NMR (400 $\left.\mathrm{MHz}, \mathrm{CDCl}_{3}\right) \delta$ ppm: 3.73-3.70 (m, 2H), 3.66-3.63 (m, 2H), 3.50-3.49 (m, 2H), 3.15-3.12 (m, 2H), $1.86-1.83(\mathrm{~m}, 2 \mathrm{H}), 1.65-1.52(\mathrm{~m}, 6 \mathrm{H}), 1.46(\mathrm{~s}, 9 \mathrm{H})$. To a solution of the free amine (658 $\mathrm{mg}, 2.58$ mmol) in $\mathrm{CH}_{2} \mathrm{Cl}_{2}(15 \mathrm{~mL}) 3 \mathrm{M} \mathrm{HCl}$ in $\mathrm{MeOH}(6.87 \mathrm{~mL}, 20.61 \mathrm{mmol})$ was added. The reaction was stirred at $\mathrm{rt}$ for $2 \mathrm{~h}$. The crude reaction was concentrated to afford the 1-oxa-9-azaspiro[5.5]undecane, hydrochloride. Off-white solid, yield 100\% (514 mg, $2.58 \mathrm{mmol}$ ). ${ }^{1} \mathrm{H}$ NMR (400 MHz, DMSO- $d_{6}$ ) $\delta$ ppm: 8.96-8.83 (m, 2H), 3.13-3.09 (m, 2H), 3.02-2.93 (m, 2H), 1.69-1.61 (m, 5H), 1.54-1.45 (m, $6 \mathrm{H})$.

Determination of MIC for M. tuberculosis. Mycobacterium tuberculosis $\mathrm{H} 37 \mathrm{Rv}$ was grown at $37^{\circ} \mathrm{C}$ in Middlebrook 7H9 broth (Difco) supplemented with $0.025 \%$ Tween 80 and $10 \%$ albumin-dextrosecatalase (ADC) or on Middlebrook 7H10 plates supplemented with $10 \%$ oleic acid-albumin-dextrose- 
catalase (OADC). The antitubercular activity against extracellular or intracellular Mycobacterium strains was performed as previously described. ${ }^{21}$

Microsomal Fraction Stability. Pooled mouse and human liver microsomes were purchased from Xenotech. Microsomes (final protein concentration $0.5 \mathrm{mg} / \mathrm{mL}, 5 \mathrm{mM} \mathrm{MgCl} 2$ ) and test compound (final substrate concentration $0.5 \mu \mathrm{M}$; final DMSO concentration $0.5 \%$ ) in $0.1 \mathrm{M}$ phosphate buffer $\mathrm{pH} 7.4$ were pre-incubated at $37{ }^{\circ} \mathrm{C}$ prior to the addition of $\mathrm{NADPH}$ (final concentration $1 \mathrm{mM}$ ) to initiate the reaction. The final incubation volume was $600 \mu \mathrm{L}$. Control samples were included for each compound tested where $0.1 \mathrm{M}$ phosphate buffer $\mathrm{pH} 7.4$ was added instead of NADPH (minus NADPH). Midazolan was included as control in every experiment. Each compound was incubated for 30 min and samples $(90 \mu \mathrm{L})$ were taken at $0,5,10,20$ and $30 \mathrm{~min}$. The minus NADPH control was sampled at 0 and $30 \mathrm{~min}$ only. The reactions were stopped by the addition of $200 \mu \mathrm{L}$ of acetonitrile:methanol (3:1) containing an internal standard, followed by centrifugation at $3700 \mathrm{rpm}$ for 15 min at $4{ }^{\circ} \mathrm{C}$ to precipitate the protein. Quantitative analysis was performed using specific LCMS/MS conditions. Data analysis: from a plot of ln peak area ratio (compound peak area/internal standard peak area) against time, the gradient of the line was determined. Subsequently, half-life and intrinsic clearance were calculated using the equations below:

Elimination rate constant $(\mathrm{k})=(-$ gradient $)$

Half life $\left(\mathrm{t}_{1 / 2}\right)(\min )=\frac{0.693}{\mathrm{k}}$

Intrinsic Clearance (CLint) $(\mathrm{mL} / \mathrm{min} / \mathrm{g}$ protein $)=\frac{\mathrm{V} 0.693}{\mathrm{t}_{1 / 2}}$

where $\mathrm{V}=$ Incubation volume $\mathrm{mL} / \mathrm{g}$ microsomal protein.

Procedure for PK Studies. For pharmacokinetic studies, C57BL/6 female mice (18-20 g) were used and compound concentrations were determined using peripheral whole blood.

All compounds were administered by intravenous route at $4 \mathrm{mg} / \mathrm{kg}$ single dose in $5 \% \mathrm{DMSO} / 20 \%$ Encapsin and by oral gavage at $50 \mathrm{mg} / \mathrm{kg}$ single dose in $1 \%$ methyl cellulose (1\% MC) or PEG400/Solutol 70:30 (compound 1). For i.v. route, aliquots of $25 \mu \mathrm{L}$ of blood were taken from the lateral tail vein by puncture from each mouse $(n=5)$ at 5,15 and 30 minutes, $1,2,4$ and 8 hours post- 
dose; for oral route aliquots of $25 \mu \mathrm{L}$ of blood were taken from the lateral tail vein by puncture from each mouse $(\mathrm{n}=5)$ at 15,30 , and 45 minutes, 1, 2, 4, 8 and 24 hours post-dose. LC-MS/MS was used as the analytical method for the establishment of compound concentration in blood. Pharmacokinetic analysis was performed by non-compartmental data analysis (NCA) with Phoenix WinNonlin 6.3 (Pharsight, Certara L.P) and supplementary analysis was performed with GraphPad Prism 6 (GraphPad Software, Inc).

Murine Model of Acute TB Infection. Specific pathogen-free, 8-10 week-old female C57BL/6 mice were purchased from Harlan Laboratories and were allowed to acclimate for one week. The experimental design for the acute assay has been previously described. ${ }^{22}$ In brief, mice were intratracheally infected with 100,000 CFU/mouse of M. tuberculosis H37Rv. Compounds were administered for 8 consecutive days starting one day after infection. One mouse was administered per product and dose. Lungs were harvested 24 hours after the last administration and all lung lobes were aseptically removed, homogenized and frozen. Homogenates were plated onto 10\% OADC-7H11 medium supplemented with activated charcoal $(0.4 \%)$ and incubated for 18 days at $37^{\circ} \mathrm{C}$. The viable CFU were converted to $\log 10$, which were then fitted to a sigmoidal dose/response curve (GraphPad Prism Software).

Cell Health. The Cell Health $(\mathrm{CH})$ assay is a 3-parameter automated imaging cell-based assay to measure the cytotoxic effect of compounds in human liver derived HepG2 cells. ${ }^{23,24}$ In brief, the key parameters measured in this assay using fluorescent staining are nuclear size, mitochondrial membrane potential and plasma membrane permeability. HepG2 cells (Biocat \#97134) were incubated with the test compounds in 384-well plates, and after $48 \mathrm{~h}$ the staining cocktail was added: Hoechst 33342 is used to stain nuclei and quantify changes in nuclear morphology; TMRM is a cationic dye that accumulates in healthy mitochondria that maintain a mitochondrial membrane potential. This dye leaks out of the mitochondria when the mitochondrial membrane potential is dissipated; TOTO-3 iodide labels nuclei of permeabilized cells and is used to measure plasma membrane permeability. 
Following 45 min incubation, the plate was sealed for reading on INCell 2000 (GE Healthcare). Each parameter produced a $\%$ of cells which were 'LIVE' or 'DEAD'. Analysis of data showed the $\mathrm{IC}_{50}$, the compound concentration that produced $50 \%$ of inhibition of growth of cells.

Hydrophobicity Assay (ChromlogD). $10 \mathrm{~mL}$ of $10 \mathrm{mM}$ DMSO stock solutions were diluted to 750 $\mathrm{mL}$ with octanol saturated phosphate buffer $\mathrm{pH} 7.4$ and $160 \mathrm{~mL}$ buffer saturated octanol in a 96-well deep well block. Blocks were sealed and inverted for 3 sets of 50 inversions, then centrifuged at $300 \mathrm{~g}$ for $20 \mathrm{~min}$. Both phases were then quantified using generic gradient UV-HPLC.

Chemiluminescent Nitrogen Detection (CLND) Solubility. $5 \mathrm{~mL}$ of $10 \mathrm{mM}$ DMSO stock solution

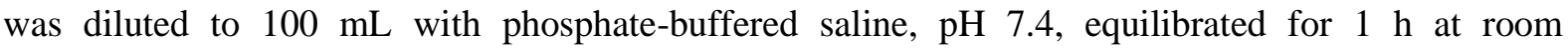
temperature, and filtered through Millipore Multiscreen HTS-PCF filter plates (MSSL BPC). The eluent was quantified by suitably calibrated flow injection CLND.

Cardiovascular Toxicity. In silico prediction of hERG inhibition in vitro was performed with DereK Nexus v.5.0.2 (Lhasa Ltd). Based on cardiovascular progression in GSK, ion channel inhibition assay was carried out through automated planar chip electrophysiology platforms, IonWorks ${ }^{25}$ and Qpatch. ${ }^{26}$ of high and medium throughput, respectively. The whole cell voltage clamp technique directly measures the effect of drugs/compounds on the hERG channel by electrophysiological method on the IonWorks Barracuda and Qpatch platform, respectively. This assay generates a full compound doseresponse curve. CHO S1 hERG cell line (BIOCAT109040) expressing KCNH2 (hERG ether-a-go-gorelated potassium channel protein) were plated in a Patchclamp plate with a 4-fold 6 concentration points dose response curve. Electrophysiology in an IonWorks Barracuda system (Molecular Devices) or Qpatch 48HTX (Sophion Bioscience, Copenhagen) was measured. Data for each well for each compound was transformed to a fraction of the baseline current and a $\mathrm{pIC}_{50}$ was obtained.

Subsequently ex vivo assay was performed to confirm the risk flagged from in vitro ion channel assays. Surgical preparation of the rabbit left ventricular wedge has been described in detail previously. ${ }^{19}$ Briefly, female New Zealand white rabbit was anaesthetized and the heart removed and immediately cannulated and perfused with cold cardioplegic solution $(24 \mathrm{mM}$ potassium $(\mathrm{K}+)$, buffered with $95 \% \mathrm{O}_{2} / 5 \% \mathrm{CO}_{2}$ ). A transmural wedge was dissected from the left ventricle. The preparation was placed in a tissue bath and arterially perfused with Tyrode's solution $(4 \mathrm{mM} \mathrm{K}+$, 
buffered with $95 \% \quad \mathrm{O}_{2} / 5 \% \quad \mathrm{CO}_{2}$, approximately $35.7{ }^{\circ} \mathrm{C}$, perfusion pressure $30-45 \mathrm{mmHg}$ ). Preparations were stimulated at a frequency of $0.5 \mathrm{~Hz}$ using a stimulating electrode applied to the endocardial surface and the ventricular wedge was allowed to equilibrate in the tissue bath for a minimum of $1 \mathrm{~h}$. A minimum of 3 preparations were exposed, in ascending order, to each concentration for approximately $30 \mathrm{~min}$. For each test concentration, a transmural ECG signal was recorded, the parameters recorded include QT interval and Tp-e interval (ms) at $0.5 \mathrm{~Hz}$, QRS interval (ms) at $0.5 \mathrm{~Hz}$. Concentration response compared to pre-treatment was conducted using 2-way ANOVA followed by Dunnett's test for statistical significance.

\section{SUPPORTING INFORMATION}

Synthetic procedures and compound characterization. List of molecular strings. Supplementary compounds already in the public domain as part of the Open Source TB (OSTB) project.

\section{AUTHOR INFORMATION}

Corresponding Authors

*M. H. T.: phone (+44) 207753 5568; e-mail matthew.todd@ucl.ac.uk

*C.A.: phone (+34) 638498619; e-mail carlos.g.alemparte@gsk.com

Notes

The authors declare no competing financial interest.

\section{ACKNOWLEDGMENTS}

We would like to thank Global Alliance for TB Drug Development for helpful discussions and financial support and all the people at GSK who have contributed to this work. We thank the Tres Cantos Open Lab Foundation for a grant (TC113).

\section{ABBREVIATIONS USED}

CFU, colony-forming unit; CLint, hepatic intrinsic clearance; CLND, chemiluminescent nitrogen detection; HepG2, hepatocellular carcinoma human; Mtb, Mycobacterium tuberculosis; MDR-TB, 
multidrug-resistant tuberculosis; MEM, minimum essential medium; O/N, overnight; PFI, property forecast index; $\mathrm{t}_{\mathrm{app}}$, apparent triplet; TdP, Torsades de Pointes; TDR-TB, totally drug-resistant tuberculosis; TMSI, trimethylsilyl iodide; XDRTB, extensively drug-resistant tuberculosis.

\section{REFERENCES}

1.

(a)

WHO

Global

Tuberculosis

Report

2018,

http://www.who.int/tb/publications/global_report/en/, accessed Nov 14, 2018. (b) Dirlikov, E.; Raviglione, M.; Scano, F. Global Tuberculosis Control: Toward the 2015 Targets and Beyond. Ann. Int. Med. 2015, 163, 52-58.

2. Zumla, A.; Nahid, P.; Cole, S. T. Advances in the Development of New Tuberculosis Drugs and Treatment Regimens. Nat. Rev. Drug Discov. 2013, 12, 388-404.

3. Working Group on New TB Drugs, http://www.newtbdrugs.org/, accessed Nov 14, 2018.

4. Günther, G. Multidrug-resistant and Extensively Drug-resistant Tuberculosis: a Review of Current Concepts and Future Challenges. Clin. Med. 2014, 14, 279-285.

5. (a) Tiberi, S.; Muñoz-Torrico, M.; Duarte, R.; Dalcolmo, M.; D’Ambrosio, L.; Migliori, G. B. New Drugs and Perspectives for New Anti-tuberculosis Regimens. Pulmonology 2018, 24, 86-98; (b) Dheda, K.; Chang, K. C.; Guglielmetti, L.; Furin, J.; Schaaf, H. S.; Chesov, D.; Esmail, A.; Lange, C. Clinical Management of Adults and Children with Multidrug-resistant and Extensively Drug-resistant Tuberculosis. Clin. Microbiol. Infect. 2017, 23, 131-140.

6. (a) Dheda, K.; Cox, H.; Esmail, A.; Wasserman, S.; Chang, K. C.; and Lange, C. Recent Controversies about MDR and XDR-TB: Global Implementation of the WHO Short-course MDR-TB Regimen and Bedaquiline for all with MDR-TB. Respirology 2018, 23, 36-45. (b) Wirth, D.; Dass, R.; Hettle, R. Cost-effectiveness of Adding Novel or Group 5 Interventions to a Background Regimen for the Treatment of Multidrug-resistant Tuberculosis in Germany. BMC Health Serv. Res. 2017, 17, 182.

7. Pai, M.; Furin, J. Tuberculosis Innovations Mean Little if they Cannot Save Lives. eLife 2017, $6, \mathrm{e} 25956$. 
8. Pethe, K.; Bifani, P.; Jang, J.; Kang, S.; Park, S.; Ahn, S.; Jiricek, J.; Jung, J.; Jeon, H. K.; Cechetto, J.; Christophe, T.; Lee, H.; Kempf, M.; Jackson, M.; Lenaerts, A. J.; Pham, H.; Jones, V.; Seo, M. J.; Kim, Y. M.; Seo, M.; Seo, J. J.; Park, D.; Ko, Y.; Choi, I.; Kim, R.; Kim, S. Y.; Lim, S.; Yim, S.-A.; Nam, J.; Kang, H.; Kwon, H.; Oh, C.-T.; Cho, Y.; Jang, Y.; Kim, J.; Chua, A.; Tan, B. H.; Nanjundappa, M. B.; Rao, S. P. S.; Barnes, W. S.; Wintjens, R.; Walker, J. R.; Alonso, S.; Lee, S.; Kim, J.; Oh, S.; Oh, T.; Nehrbass, U.; Han, S.-J.; No, Z.; Lee, J.; Brodin, P.; Cho, S.-N.; Nam, K.; Kim, J. Discovery of Q203, a Potent Clinical Candidate for the Treatment of Tuberculosis. Nat. Med. 2013, 19, 1157-1160.

9. $\quad$ Brigden, G.; Castro, J. L.; Ditiu, L.; Gray, G.; Hanna, D.; Low, M.; Matsoso, M. P.; Perry, G.; Spigelman, M.; Swaminathan, S.; Torreele, E.; Wong, S. Tuberculosis and Antimicrobial Resistance New Models of Research and Development Needed. Bull. World Health Organ. 2017, 95, 315.

10. Ballell, L.; Bates, R. H.; Young, R. J.; Alvarez-Gomez, D.; Alvarez-Ruiz, E.; Barroso, V.; Blanco, D.; Crespo, B.; Escribano, J.; González, R.; Lozano, S.; Huss, S.; Santos-Villarejo, A.; Martín-Plaza, J. J.; Mendoza, A.; Rebollo-Lopez, M. J.; Remuiñan-Blanco, M.; Lavandera, J. L.; Pérez-Herran, E.; Gamo-Benito, F. J.; García-Bustos, J. F.; Barros, D.; Castro, J. P.; Cammack, N. Fueling Open-Source Drug Discovery: 177 Small-Molecule Leads against Tuberculosis. ChemMedChem 2013, 8, 313-321.

11. Remuiñán, M. J.; Pérez-Herrán, E.; Rullás, J.; Alemparte, C.; Martínez-Hoyos, M.; Dow, D. J.; Afari, J.; Mehta, N.; Esquivias, J.; Jiménez, E.; Ortega-Muro, F.; Fraile-Gabaldón, M. T.; Spivey, V. L.; Loman, N. J.; Pallen, M. J.; Constantinidou, C.; Minick, D. J.; Cacho, M.; Rebollo-López, M. J.; González, C.; Sousa, V.; Angulo-Barturen, I.; Mendoza-Losana, A.; Barros, D.; Besra, G. S.; Ballell, L.; Cammack, N. Tetrahydropyrazolo[1,5-a]Pyrimidine-3-Carboxamide and N-Benzyl-6',7'Dihydrospiro[Piperidine-4,4'-Thieno[3,2-c]Pyran] Analogues with Bactericidal Efficacy against Mycobacterium tuberculosis Targeting MmpL3. PLoS One 2013, 8, e60933.

12. Domenech, P.; Reed, M. B.; Barry, C. E. Contribution of the Mycobacterium tuberculosis MmpL Protein Family to Virulence and Drug Resistance. Infection and Immunity 2005, 73, 34923501. 
13. (a) Ioerger, T. R.; O’Malley, T.; Liao, R.; Guinn, K. M.; Hickey, M. J.; Mohaideen, N.; Murphy, K. C.; Boshoff, H. I. M.; Mizrahi, V.; Rubin, E. J.; Sassetti, C. M.; Barry, C. E., III; Sherman, D. R.; Parish, T.; Sacchettini, J. C. Identification of New Drug Targets and Resistance Mechanisms in Mycobacterium tuberculosis. PLoS One 2013, 8, e75245. (b) Tahlan, K.; Wilson, R.; Kastrinsky, D. B.; Arora, K.; Nair, V.; Fischer, E.; Barnes, S. W.; Walker, J. R.; Alland, D.; Barry, C. E.; Boshoff, H. I. SQ109 Targets MmpL3, a Membrane Transporter of Trehalose Monomycolate Involved in Mycolic Acid Donation to the Cell Wall Core of Mycobacterium tuberculosis. Antimicrob. Agents Chemother. 2012, 56, 1797-1809.

14. (a) Belardinelli, J. M.; Yazidi, A.; Yang, L.; Fabre, L.; Li, W.; Jacques, B.; Angala, S. k.; Rouiller, I.; Zgurskaya, H. I.; Sygusch, J.; Jackson, M., Structure-Function Profile of MmpL3, the Essential Mycolic Acid Transporter from Mycobacterium tuberculosis. ACS Infec.Dis. 2016, 2, 702713; (b) Li, W.; Upadhyay, A.; Fontes, F. L.; North, E. J.; Wang, Y.; Crans, D. C.; Grzegorzewicz, A. E.; Jones, V.; Franzblau, S. G.; Lee, R. E.; Crick, D. C.; Jackson, M., Novel Insights into the Mechanism of Inhibition of MmpL3, a Target of Multiple Pharmacophores in Mycobacterium tuberculosis. Antimicrob. Agents Chemother. 2014, 58, 6413-6423.

15. Dansette, P. M.; Amar, C.; Smith, C.; Pons, C.; Mansuy, D. Oxidative Activation of the Thiophene Ring by Hepatic Enzymes: Hydroxylation and Formation of Electrophilic Metabolites During Metabolism of Tienilic Acid and its Isomer by Rat Liver Microsomes. Biochem. Pharmacol. 1990, 39, 911-918.

16. Badiola, K. A.; Quan, D. H.; Triccas, J. A.; Todd, M. H. Efficient Synthesis and AntiTubercular Activity of a Series of Spirocycles: An Exercise in Open Science. PLoS One 2014, 9, e111782.

17. (a) Yeates, C. L.; Batchelor, J. F.; Capon, E. C.; Cheesman, N. J.; Fry, M.; Hudson, A. T.; Pudney, M.; Trimming, H.; Woolven, J.; Bueno, J. M.; Chicharro, J.; Fernández, E.; Fiandor, J. M.; Gargallo-Viola, D.; Gómez de las Heras, F.; Herreros, E.; León, M. L. Synthesis and StructureActivity Relationships of 4-Pyridones as Potential Antimalarials. J. Med. Chem. 2008, 51, 28452852; (b) Murugesan, D.; Mital, A.; Kaiser, M.; Shackleford, D. M.; Morizzi, J.; Katneni, K.; Campbell, M.; Hudson, A.; Charman, S. A.; Yeates, C. Gilbert, I. H., Discovery and Structure- 
Activity Relationships of Pyrrolone Antimalarials. J. Med. Chem. 2013, 56, 2975-2990; (c) Williamson, A. E.; Ylioja, P. M.; Robertson, M. N.; Antonova-Koch, Y.; Avery, V.; Baell, J. B.; Batchu, H.; Batra, S.; Burrows, J. N.; Bhattacharyya, S.; Calderon, F.; Charman, S. A.; Clark, J.; Crespo, B.; Dean, M.; Debbert, S. L.; Delves, M.; Dennis, A. S. M.; Deroose, F.; Duffy, S.; Fletcher, S.; Giaever, G.; Hallyburton, I.; Gamo, F.-J.; Gebbia, M.; Guy, R. K.; Hungerford, Z.; Kirk, K.; Lafuente-Monasterio, M. J.; Lee, A.; Meister, S.; Nislow, C.; Overington, J. P.; Papadatos, G.; Patiny, L.; Pham, J.; Ralph, S. A.; Ruecker, A.; Ryan, E.; Southan, C.; Srivastava, K.; Swain, C.; Tarnowski, M. J.; Thomson, P.; Turner, P.; Wallace, I. M.; Wells, T. N. C.; White, K.; White, L.; Willis, P.; Winzeler, E. A.; Wittlin, S.; Todd, M. H. Open Source Drug Discovery: Highly Potent Antimalarial Compounds Derived from the Tres Cantos Arylpyrroles. ACS Cent. Sci. 2016, 2, 687-701.

18. Young, R. J.; Green, D. V. S.; Luscombe, C. N.; Hill, A. P. Getting Physical in Drug Discovery II: the Impact of Chromatographic Hydrophobicity Measurements and Aromaticity. Drug Discovery Today 2011, 16, 822-830.

19. Yan, G.-X.; Wu, Y.; Liu, T.; Wang, J.; Marinchak, R. A.; Kowey, P. R.. Phase 2 Early Afterdepolarization as a Trigger of Polymorphic Ventricular Tachycardia in Acquired Long-QT Syndrome. Circulation 2001, 103, 2851-2856.

20. OpenSourceTB: OSTB Series 1. https://github.com/OpenSourceTB/OSTB_Series_1, accessed Nov 14, 2018.

21. Blanco-Ruano, D.; Roberts, D. M.; Gonzalez-Del-Rio, R.; Alvarez, D.; Rebollo, M. J.; PerezHerran, E.; Mendoza, A., Antimicrobial Susceptibility Testing for Mycobacterium sp. In Mycobacteria Protocols.; Parish T., Roberts D., Eds.; Humana Press, New York, 2015; pp 257-268.

22. Rullas, J.; Garcia, J. I.; Beltran, M.; Cardona, P. J.; Caceres, N.; Garcia-Bustos, J. F.; AnguloBarturen, I., Fast Standardized Therapeutic-efficacy Assay for Drug Discovery against Tuberculosis. Antimicrob. Agents Chemother. 2010, 54, 2262-2264.

23. O'Brien, P. J.; Edvardsson, A. Validation of a Multiparametric, High-Content-Screening Assay for Predictive/Investigative Cytotoxicity: Evidence from Technology Transfer Studies and Literature Review. Chem. Res. Toxicol. 2017, 30, 804-829. 
24. Sison-Young, R. L.; Lauschke, V. M.; Johann, E.; Alexandre, E.; Antherieu, S.; Aerts, H.; Gerets, H. H. J.; Labbe, G.; Hoët, D.; Dorau, M.; Schofield, C. A.; Lovatt, C. A.; Holder, J. C.; Stahl, S. H.; Richert, L.; Kitteringham, N. R.; Jones, R. P.; Elmasry, M.; Weaver, R. J.; Hewitt, P. G.; Ingelman-Sundberg, M.; Goldring, C. E.; Park, B. K. A Multicenter Assessment of Single-cell Models Aligned to Standard Measures of Cell Health for Prediction of Acute Hepatotoxicity. Arch. Toxicol. 2017, 91, 1385-1400.

25. Gillie, D. J.; Novick, S. J.; Donovan, B. T.; Payne, L. A.; Townsend, C. Development of a High-throughput Electrophysiological Assay for the Human Ether-à-go-go Related Potassium Channel hERG. J. Pharmacol. Toxicol. Methods 2013, 67, 33-44.

26. Korsgaard, M. P. G.; Strobaek, D.; Christophersen, P. Automated Planar Electrode Electrophysiology in Drug Discovery: Examples of the Use of QPatch in Basic Characterization and High Content Screening on Nav, KCa2.3, and Kv11.1 Channels. Comb. Chem. High Throughput Screen. 2009, 12, 51-63.

\section{TABLE OF CONTENTS GRAPHIC}

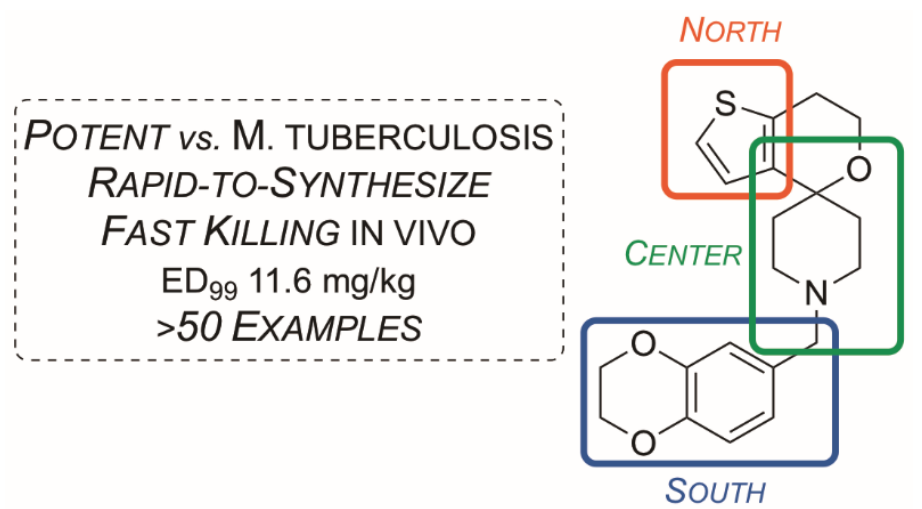

